\title{
Komunikasi dan Adaptasi Pernikahan Kembali Sesudah Bercerai
}

\author{
Novi Andayani Praptiningsih \\ Universitas Padjadjaran \\ E-mail:noviap1711@gmail.com
}

\begin{abstract}
Abstrak
Menikah kembali setelah bercerai menjadi solusi yang dapat membantu individu tidak hanya mendapatkan teman hidup yang bisa dipercaya dan diajak berbagi serta pasangan dalam hubungan seksual, tetapi menikah lagi juga dapat meningkatkan kesejahteraan ekonomi. Di samping itu juga akan mendapatkan makna hidup yang lebih positif. Tujuan penelitian ini adalah untuk mengetahui alasan, motif, dan konsep diri perempuan yang melakukan pernikahan kembali sesudah bercerai sehubungan dengan pilihan hidupnya, serta untuk memahami proses komunikasi dan adaptasi dengan keluarga barunya. Teori yang digunakan dalam penelitian Komunikasi Antar Pribadi ini menggunakan Teori Interaksi Simbolik George Herbert Mead serta Teori Konstruksi Realitas Sosial Peter Berger dan Thomas Luckman. Paradigma penelitian interpretif, menggunakan metode penelitian fenomenologi dengan pendekatan kualitatif. Teknik penentuan informan menggunakan teknik persuasif. Teknik pengumpulan dengan wawancara mendalam terhadap lima perempuan yang melakukan pernikahan kembali sesudah bercerai, serta studi pustaka.

Hasil penelitian menunjukkan subjek memutuskan untuk menikah kembali setelah perceraian karena alasan biologis, ekonomi, dan sosial/agama. Sedangkan motifnya berorientasi masa lalu dan masa depan sehingga konsep diri yang terbentuk pada masa awal pasca perceraian adalah konsep diri negatif dan konsep diri positif mulai terbentuk ketika mereka memutuskan untuk menikah lagi pasca perceraiannya. Dan proses komunikasi dalam adaptasi dengan keluarga barunya membutuhkan waktu yang cukup lama untuk saling memahami satu sama lain. Proses penyesuaian diri tersebut menemui banyak hambatan komunikasi. Sikap diam dan terkesan menghindar ditunjukkan oleh subjek penelitian ketika ada hal-hal yang mengganggu perasaan mereka dalam hubungan dengan keluarga baru. Namun akhirnya mereka menyadari bahwa adaptasi yang dilakukan harus didukung oleh komunikasi yang terbuka untuk mengungkapkan segala persoalan yang dihadapi agar menemukan cara penyelesaiannya.
\end{abstract}

Kata kunci : komunikasi antar pribadi, komunikasi, adaptasi, pernikahan kembali,

\section{bercerai Abstract}

Remarriage after divorce is a solution that can help individuals not only get a mate who can be trusted and invited to share as well as couples in a sexual relationship, but remarried can also improve economic welfare. In addition, it also will get more positive meaning of life. The purpose of this study was to find out the reasons, motives, and self-concept of women who do remarriage after divorce in connection with the choice of his life, as well as to understand the communication process and adaptation to his new family. The theory used in this Interpersonal Communication Research are Symbolic Interaction Theory George Herbert Mead and the Theory Construction of Social Reality Peter Berger and Thomas Luckman. Research paradigm is interpretive, phenomenological research methods with a qualitative approach. Technique of determining the informant use persuasive techniques. Collection techniques depth interviews with five women who did remarriage after divorce, as well as literature. 
The results showed the subject decided to remarry after divorce for reasons of biological, economic, and social / religious. While the motive is oriented past and future so that the concept of self is formed in the early days after the divorce is a negative self-concept and positive self-concept began to take shape when they decide to get married again after divorce. And communication processes in the adaptation with his new family requires considerable time to understand each other. The adjustment process to meet a lot of communication barriers. Silence and impressed avoid shown by the study subjects when there are things that interfere with their feelings in a relationship with a new family. But they finally realized that the adaptations made to be supported by open communication to reveal all the problems faced in order to find a way to resolve it.

Keywords: interpersonal communication, communication, adaptation, remarriage, divorce 


\section{PENDAHULUAN}

\section{A. Konteks Penelitian}

Pernikahan merupakan awal dari suatu kehidupan bersama dengan pasangan dan kesiapan seseorang dalam membina sebuah keluarga. Keluarga adalah pasangan yang menikah atau kelompok keluarga besar yang saling bekerjasama dan membagi tugas pada setiap anggota keluarga, menjaga anak-anak, dan berbagi tempat tinggal. Keluarga secara ideal terdiri dari suami dan istri orang tua) serta anak. Pernikahan dan keluarga terdiri dari individuindividu dengan perbedaan kepribadian, ide, nilai, cita rasa, dan tujuan.

Sebuah perkawinan tidak selamanya dapat bertahan hingga terjadi perceraian sebagai jalan terakhir bagi sebagian orang. Saat ini, perceraian memang tidak lagi dipandang sebagai sesuatu hal yang memalukan namun sudah menjadi hal yang biasa dalam masyarakat, walaupun Allah Swt membencinya. Pada beberapa penelitian menunjukkan bahwa kecenderungan gugatan cerai lebih banyak dilakukan oleh wanita. Hal ini dapat disebabkan karena pasangan atau wanita yang melakukan gugatan cerai melihat perceraian sebagai solusi untuk mengatasi masalah-masalah yang timbul dalam pernikahan yang tidak dapat diatasi lagi oleh kedua pasangan. Meskipun demikian, perceraian seringkali diartikan sebagai kegagalan yang dialami suatu keluarga, sekaligus aib bagi keluarga besar kedua belah pihak. Suatu perceraian yang ditandai dengan adanya proses kehilangan secara tiba-tiba tentu menimbulkan konsekuensi-konsekuensi bagi kedua belah pihak. Di satu sisi, dengan bercerai individu dapat bebas dari tekanan, mengurangi konflik batin yang dialami selama pernikahan serta membuka kesempatan untuk membangun kehidupan baru yang lebih baik. Di sisi lain, perceraian juga menimbulkan konsekuensi berupa timbulnya masalah-masalah pasca perceraian seperti masalah ekonomi, masalah praktis kegiatan rumah tangga sehari-hari, masalah psikologis, masalah emosional, masalah sosial, masalah kesepian, masalah pembagian tanggung jawab pengasuhan anak, masalah seksual, dan masalah perubahan konsep diri.

Melihat pada konsekuensi-konsekuensi yang muncul dari perceraian, maka masalah utama yang perlu dihadapi setelah perceraian dapat berupa penyesuaian kembali (readjustment) dengan status hidup sendiri tanpa pasangan, atau yang disebut dengan duda atau janda. Dengan status baru sebagai janda apalagi yang memiliki anak, wanita harus berperan sebagai orang tua tunggal dan harus bisa mengatur ekonomi keluarga secara mandiri. Sebagai orang tua tunggal wanita harus bisa berperan ganda yaitu sebagai ayah yang fungsinya mencari nafkah dan sebagai ibu yang berperan membesarkan dan mendidik anak. Hal ini dikarenakan bahwa kondisi keuangan wanita hampir selalu memburuk setelah perceraian, terutama jika dia memiliki anak.

Menikah lagi menjadi solusi yang dapat membantu individu untuk mengatasi persoalan yang muncul. Menikah lagi dapat membantu penyesuaian diri, tidak hanya untuk mendapatkan teman yang bisa dipercaya dan diajak berbagi serta pasangan dalam hubungan seksual, tetapi menikah lagi juga dapat meningkatkan kesejahteraan ekonomi. Menikah lagi dapat mengarahkan individu pada penyesuaian diri yang lebih baik dan mendapatkan makna hidup yang lebih positif.

Beberapa alasan yang mendorong individu untuk menikah lagi antara lain untuk mendapatkan cinta dan persahabatan, pemenuhan kebutuhan biologis, faktor kebutuhan ekonomi/ keuangan, etika, moral, dan norma sosial, faktor pemeliharaan atau pendidikan anak serta 
untuk memperoleh status sosial.

Berdasarkan uraian di atas, penelitian ini bertujuan untuk mengetahui konstruksi realitas sosial yang dapat dipahami dari alasan, motif, dan konsep diri subjek yang diteliti. Dengan demikian dalam penelitian ini, peneliti menggunakan metode penelitian fenomenologi yakni sebuah pendekatan bagaimana dunia di dalam pengalaman pelaku dengan didasari asumsi epistemologis bahwa kenyataan adalah apa yang ada di dalam bayangan dari pelaku. Penelitian ini berada pada paradigma interpretif yang melihat pengalaman manusia terdiri dari intrepretasi bermakna terhadap kenyataan.

Menurut salah satu tokoh fenomenologi, Edmund Husserl [Kuswarno, 2009, p.10]. Dengan fenomenologi kita dapat mempelajari bentuk-bentuk pengalaman dari sudut pandang orang yang mengalaminya secara langsung, seolah-olah kita mengalaminya sendiri. Fenomenologi tidak saja mengklasifikasikan setiap tindakan sadar yang dilakukan, namun juga meliputi prediksi terhadap tindakan di masa yang akan datang, dilihat dari aspek-aspek yang terkait dengannya. Semuanya itu bersumber dari bagaimana seseorang memaknai objek dalam pengalamannya. Oleh karena itu , tidak salah apabila fenomenologi juga diartikan sebagai studi tentang makna, dimana makna itu lebih luas dari sekedar bahasa yang mewakilinya.

Dari penjelasan di atas, penelitian ini bermaksud mempelajari bentuk-bentuk pengalaman dari sudut pandang orang yang mengalaminya secara langsung, juga diartikan sebagai studi tentang makna, dimana makna itu lebih luas dari sekedar bahasa yang mewakilinya, dalam hal ini pada perempuan yang melakukan pernikahan kembali sesudah bercerai.

Teori yang mendukung kajian ini adalah Teori Interaksi Simbolik (George Herbert Mead dan Herbert Blumer). Para ahli perspektif interaksionisme simbolik melihat bahwa individu adalah obyek yang bisa secara langsung ditelaah dan dianalisis melalui interaksinya dengan individu yang lain. Mereka menemukan bahwa individu-individu tersebut berinteraksi dengan menggunakan simbol-simbol, yang di dalamnya berisi tandatanda, isyarat dan kata-kata. Simbol atau lambang adalah sesuatu yang digunakan untuk menunjuk sesuatu lainnya, berdasarkan kesepakatan sekelompok orang. Lambang meliputi kata-kata (pesan verbal), perilaku nonverbal, dan objek yang disepakati bersama [Mulyana, 2008, p. 84]. Aplikasi teori tersebut dalam penelitian ini adalah bahwa perempuan pelaku remarriage berinteraksi dengan menggunakan simbol-simbol yang di dalamnya berisi tanda-tanda, isyarat dan kata-kata dalam memaknai remarriage.

Jika perilaku remarriage dianggap sebagai sebuah perilaku negatif bagi sebagian orang, maka pandangan ini bukan kesalahan pemikiran melainkan sebuah pemikiran yang melihat perempuan pelaku pernikahan kembali sesudah bercerai dari sudut pandang orang luar (pandangan etik), sebagai sebuah fakta yang semestinya berlaku seperti itu, bukan pandangan emik (bagaimana perempuan pelaku remarriage melihat kehidupan mereka sendiri).

Dalam pandangan interpretif, perempuan pelaku pernikahan kembali sesudah bercerai adalah subjek. Mereka adalah "aktor kehidupan" yang memiliki hasrat, harapan, dan kehidupan sendiri yang unik. Pandangan subjektif seperti ini diperlukan untuk mengimbangi pandangan sebelumnya yang objektif yang melihat perempuan pelaku pernikahan kembali sesudah bercerai sebagai individu yang mengalami kegagalan berumah tangga bukan sebagai entitas masyarakat yang memiliki pemikiran dan pengalaman hidup yang mereka rasakan dan alami sendiri. 
Berbagai kajian dapat digunakan untuk mengungkapkan fenomena pernikahan kembali, salah satunya adalah komunikasi. Pendekatan interaksi simbolik sebagai suatu pendekatan komunikasi dapat digunakan untuk menjelaskan bagaimana fenomena perempuan pelaku pernikahan kembali sesudah bercerai melakukan adaptasi dengan lingkungannya termasuk dengan keluarga barunya. Studi ini juga akan mengungkapkan alasan atau motivasi apa yang mendorong mereka memutuskan untuk menikah kembali setelah perceraian.

\section{B. Perumusan Masalah}

Berdasarkan uraian yang telah dikemukakan di atas, maka terdapat dua pertanyaan umum sebagai masalah penelitian ini, yaitu :

1. Apakah alasan, motif, dan konsep diri perempuan yang melakukan pernikahan kembali sesudah bercerai?

2. Bagaimana proses komunikasi dan adaptasi dengan keluarga barunya perempuan yang melakukan pernikahan kembali sesudah bercerai?

\section{Tujuan Penelitian}

Tujuan penelitian ini adalah sebagai berikut:

1. Untuk mengetahui dan memahami alasan, motif, dan konsep diri perempuan yang melakukan pernikahan kembali sesudah bercerai sehubungan dengan pilihan hidupnya.

2. Untuk mengetahui dan memahami proses komunikasi dan adaptasi dengan keluarga barunya perempuan yang melakukan pernikahan kembali sesudah bercerai

\section{Manfaat Penelitian}

Manfaat/Signifikansi penelitian ini adalah :

1. Secara teoritis, hasil penelitian ini diharapkan dapat memperkaya kajian dalam bidang komunikasi, terutama tentang konstruksi makna terhadap fenomena tertentu.

2. Secara praktis, penelitian ini diharapkan dapat membantu memecahkan masalah yang berkaitan dengan konstruksi makna menikah lagi, menjadi masukan bagi pasangan suami istri untuk memahami komunikasi dan adaptasi dengan keluarga baru pada pernikahan kedua.

\section{TINJAUAN PUSTAKA A.}

\section{Teori-teori Pendukung}

Teori yang digunakan dalam konteks penelitian komunikasi antar pribadi (Interpersonal Communication), sebagai berikut :

\section{Teori Konstruksi Realitas Sosial Peter Berger dan Thomas Luckman}

Salah satu mahasiswa Schutz yang tertarik dengan pembahasan tentang konstruksi realitas secara sosial adalah Peter Berger. Berger mampu mengembangkan model teoretis lain mengenai bagaimana dunia sosial terbentuk. Dia menganggap realitas sosial eksis dengan sendirinya dan struktur dunia sosial bergantung pada manusia yang menjadi subjeknya. Dengan demikian, dia berpendapat bahwa realitas sosial secara objektif memang ada (seperti pada perspektif fungsionalis), tetapi maknanya berasal dari dan oleh hubungan subjektif 
(individu) dengan dunia objektif (suatu perspektif interaksionis simbolis).

Bersama dengan Thomas Luckmann, Berger menuangkan pikiran tentang kosntruksi sosial dalam buku berjudul The Social Construction of Reality. Berger dan Luckmann dalam bukunya menyebutkan bahwa seseorang hidup dalam kehidupannya mengembangkan suatu perilaku repetitif, yang mereka sebut sebagai "kebiasaan" (habits). Kebiasaan ini memungkinkan seseorang mengatasi suatu situasi secara otomatis. Kebiasaan seseorang ini berguna juga untuk orang lain. Dalam situasi komunikasi interpersonal, para partisipan ("aktor" menurut Schutz) saling mengamati dan merespon kebiasaan orang lain, dan dengan cara seperti ini semua partisipan dapat mengantisipasi dan menggantungkan diri pada kebiasaan orang lain tersebut. Karena kebiasaan ini, seseorang dapat membangun komunikasi dengan orang lain yang disesuaikan dengan tipe-tipe seseorang, yang disebut sebagai pengkhasan (typication). Dengan berjalannya waktu, kenyataan selanjutnya, beberapa kebiasaan menjadi milik bersama seluruh anggota masyarakat, maka terbentuklah sebuah lembaga (institution).

Terkait dengan fenomenologi, saat ini Schutz dikenal sebagai ahli fenomenologi yang paling menonjol. Oleh karena itu ia mampu membuat ide-ide Husserl yang masih dirasakan sangat abstrak, menjadi lebih mudah dipahami. Dia jugalah yang membawa fenomenologi ke dalam ilmu sosial, membuat fenomenologi menjadi ciri khas bagi ilmu sosial hingga saat ini. Baginya tugas fenomenologi adalah menghubungkan antara pengetahuan ilmiah dengan pengalaman sehari-hari, dan dari kegiatan di mana pengelaman dan pengetahuan itu berasal. Dengan kata lain mendasarkan tindakan sosial pada pengalaman, makna dan kesadaran.

Menurut Schutz, manusia mengkonstruksi makna di luar arus utama pengalaman melalui proses "tipikasi". Hubungan antar makna pun diorganisasi melalui proses ini, atau biasa disebut stock of knowledge. Jadi kumpulan pengetahuan memiliki kegunaan praktis dari dunia itu sendiri, bukan sekedar pengetahuan tentang dunia.

Inti pemikiran Schutz adalah bagaimana memahami tindakan sosial melalui penafsiran. Proses penafsiran dapat digunakan untuk memperjelas atau memeriksa makna yang sesungguhnya, sehingga dapat memberikan konsep kepekaan yang implisit. Schutz meletakkan hakikat manusia dalam pengalaman subjektif, terutama ketika mengambil tindakan dan mengambil sikap terhadap dunia kehidupan sehari-hari. Dalam hal ini, Shutz mengikuti pemikiran Husserl, yaitu proses pemahaman aktual kegiatan kita, dan pemberian makna terhadapnya, sehingga terefleksi dalam tingkah laku.

Dalam pandangan Schutz, manusia adalah makhluk sosial, sehingga kesadaran akan dunia kehidupan sehari-hari adalah sebuah kesadaran sosial. Dunia individu merupakan dunia intersubjektif dengan makna beragam, dan perasaan sebagai bagian dari kelompok. Manusia dituntut untuk saling memahami satu sama lain, dan bertindak dalam kenyataan yang sama. Dengan demikian ada penerimaan timbal balik, pemahaman atas dasar pengalaman bersama, dan tipikasi atas dunia bersama. Melalui tipikasi inilah manusia belajar menyesuaikan diri ke dalam dunia yang lebih luas, dengan juga melihat diri kita sendiri sebagai orang yang memainkan peran dalam situasi tipikal.

Hubungan-hubungan sosial antar manusia ini kemudian membentuk totalitas masyarakat. Jadi, dalam kehidupan totalitas masyarakat, setiap individu menggunakan simbol-simbol yang telah diwariskan padanya, untuk memberi makna pada tingkah lakunya sendiri. Singkatnya pandangan deskriptif atau interpretatif mengenai tindakan sosial, dapat diterima 
jika tampak masuk akal bagi pelaku sosial yang relevan.

Ide-ide Schutz ini mengasumsikan dunia kehidupan sebagai dunia yang tidak problematis. Mungkin saja karena Schutz bekerja dalam ritme kehidupan yang tidak problematis. Dengan demikian pemikiran Schutz ini hanya akan menangkap makna tindakan orang awam, sebagaimana orang awam itu sendiri memahami tindakannya.

Institusi memungkinkan berkembangnya suatu peranan (role), atau kumpulan perilaku yang terbiasa (habitual behavior) dihubungkan dengan harapan-harapan individu yang terlibat. Ketika seseorang memainkan peranan yang dia adopsi dari perilaku yang terbiasa, orang lain berinteraksi dengannya sebagai suatu bagian dari institusi tersebut ketimbang sebagai individu yang unik. Pada institusi tersebut juga berkembang apa yang disebut sebagai hukum (law). Hukum ini yang mengatur berbagai peranan.

Oleh karena aktor telah menetapkan hukum berperilaku, maka institusi menjadi sebuah kendali sosial. Jika kendali sosial ini akan dipertahankan dalam waktu lama, maka generasi berikutnya harus diajari untuk berpartisipasi di dalam institusi oleh para orang tua mereka. Dengan demikian institusi tersebut institusi tersebut akan terlegitimasi dan terpelihara melalui tradisi dan edukasi.

Jika suatu institusi bertahan dalam waktu lama, masyarakat dapat lupa bagaimana institusi itu terbentuk awalnya. Pada kasus ini, masyarakat dapat mulai membayangkan bagaimana institusi tersebut selalu dapat eksis; kondisi ini akan "menjadi kembali" (came to be) seperti pada awal terbentuknya. Kondisi ini disebut sebagai "pembedaan" (refication) dan institusi dikatakan "dibendakan" (reified).

\section{Teori Interaksi Simbolik George Herbert Mead}

Selain teori di atas, fenomena perilaku pelaku menikah kembali sesudah bercerai dapat dilihat dari pandangan teori Interaksi Simbolik. Titik tolak pemikiran interaksi simbolik berasumsi bahwa realitas sosial sebagai sebuah interaksi simbolik individu-individu yang ada di dalamnya. Pada hakikatnya tiap manusia sebagai proses dan bukan sesuatu yang bersifat statis. Dalam hal ini masyarakat dipandang bukanlah "barang jadi" melainkan barang yang "akan jadi" karena itu teori interaksi simbolik membahas pula konsep mengenai "diri" (self) yang tumbuh berdasarkan suatu "negosiasi" makna dengan orang lain. Menurut George Herbert Mead, cara manusia mengartikan dunia dan dirinya sendiri berkaitan erat dengan masyarakatnya. Mead melihat pikiran (mind) dan dirinya (self) menjadi bagian dari perilaku manusia yaitu bagian interaksinya dengan orang lain. Mead menambahkan bahwa sebelum seorang bertindak, ia membayangkan dirinya dalam posisi orang lain dengan harapan-harapan orang lain dan mencoba memahami apa yang diharapkan orang itu [Littlejohn, p. 207].

Konsep diri (self consept) merupakan suatu bagian yang penting dalam setiap pembicaraan tentang kepribadian manusia. Konsep diri merupakan sifat yang unik pada manusia sehingga dapat digunakan untuk membedakan manusia dari makhluk hidup lainnya. Keunikan konsep diri pada setiap individu pun relatif berbeda-beda karena antara individu-individu dengan individu lainnya mempunyai pola pikir yang berbeda. Konsep diri terbentuk dan dapat berubah karena interaksi dengan lingkungannya. Perkembangan yang berlangsung tersebut kemudian membantu pembentukan konsep diri individu yang membantu pembentukan konsep diri individu yang bersangkutan. Konsep diri yang dimiliki individu dapat diketahui 
melalui informasi, pendapat, dan penilaian atau evaluasi orang lain. Diri juga terdiri menjadi dua bagian yaitu dari obyek yang mengalami kepuasan atau kurang mengalami kepuasan diri yang bertindak dalam melayani diri obyek yang berupaya memberinya kepuasan.

Menurut Mead, tubuh bukanlah diri dan baru menjadi diri ketika pikiran telah berkembang. Sementara di sisi lain bersama refleksivitasnya, diri adalah sesuatu yang mendasar bagi perkembangan pikiran. Tentu saja mustahil memisahkan pikiran dari diri, karena diri adalah proses mental. Namun, meskipun kita bisa saja menganggapnya sebagai proses mental, diri adalah proses sosial. Mekanisme umum perkembangan diri adalah refleksivitas atau kemampuan untuk meletakkan diri kita secara bawah sadar di tempat orang lain serta bertindak sebagaimana mereka bertindak. Akibatnya, orang mampu menelaah dirinya sendiri sebagaimana orang lain menelaahnya.

Dengan menyerasikan diri dengan harapan-harapan orang lain, dimungkinkan terjadi interaksi. Semakin mampu seseorang mengambil alih atau menerjemahkan perasaanperasaan sosial semakin terbentuk identitas atau kediriannya. Ada tiga premis yang dibangun dalam interaksi simbolik yaitu :

1. Manusia bertindak terhadap sesuatu berdasarkan makna-makna yang ada pada sesuatu itu bagi mereka.

2. Makna tersebut berasal dari "interaksi sosial seseorang dengan orang lain".

3. Makna-makna tersebut disempurnakan di saat proses interaksi sosial berlangsung. [Kuswarno, 2009, p. 113]

Bagi Mead, "diri" lebih dari sebuah internalisasi struktur sosial dan budaya. "Diri" juga merupakan proses sosial, sebuah proses di mana para pelaunya memperlihatkan pada dirinya sendiri hal-hal yang dihadapinya, di dalam situasi di mana ia bertindak dan merencanakan tindakannya itu melalui penafsirannya atas hal-hal tersebut. Dalam hal ini, aktor atau pelaku yang melakukan interaksi sosial dengan dirinya sendiri. Menurut Mead dilakukan dengan cara mengambil peran orang lain dan bertindak berdasarkan peran tersebut, lalu memberikan respon atas tindakan-tindakan itu. Konsep interaksi pribadi (self interaction) di mana para pelaku menunjuk diri mereka sendiri berdasarkan pada skema Mead mengenai psikologi sosial. "Diri" di sini bersifat aktif dan kreatif serta tidak ada satu pun variabel-variabel sosial, budaya, maupun psikologis yang dapat memutuskan tindakan-tindakan "diri".

Mead menyatakan bahwa konsep diri pada dassarnya terdiri dari jawaban individu atas pertanyaan mengenai "siapa aku" untuk kemudian dikumpulkan dalam bentuk kesadaran diri individu mengenai keterlibatannya yang khusus dalam seperangkat hubungan sosial yang sedang berlangsung. Pendapat Mead tentang pikiran adalah bahwa pikiran mempunyai corak sosial, percakapan dalam batin adalah percakapan antara "aku" dengan "yang lain". Pada titik ini, konsepsi tentang "aku" itu sendiri merupakan orang lain terhadap individu tersebut. Atau dengan kalimat singkat, individu mengambil pandangan orang lain mengenai dirinya seolaholah pandangan tersebut adalah "dirinya" yang berasal dari "aku".

Interaksionisme simbolik mengandung inti dasar pemikiran umum tentang komunikasi dan masyarakat. Jerome Manis dan Bernard Meltzer memisahkan tujuh hal mendasar yang bersifat teoritis dan metodologis dari interaksionisme simbolik, yaitu :

1. Orang-orang dapat mengerti berbagai hal dengan belajar dari pengalaman. Persepsi seseorang selalu diterjemahkan dalam simbol-simbol.

2. Orang-orang dapat mengerti berbagai hal dengan belajar dari pengalaman. Persepsi 
seseorang selalu diterjemahkan dalam simbol-simbol.

3. Berbagai arti dipelajari melalui interaksi di antara orang-orang. Arti muncul dari adanya pertukaran simbol-simbol dalam kelompok-kelompok sosial.

4. Seluruh struktur dan institusi sosial diciptakan dari adanya interaksi di antara orangorang.

5. Tingkah laku seseorang tidaklah mudah ditentukan oleh kejadian-kejadian pada masa lampau saja, tetapi juga dilakukan secara sengaja.

6. Pikiran terdiri dari percakapan internal yang merefleksikan interaksi yang telah terjadi antara seseorang dengan orang lain.

7. Tingkah laku terbentuk atau tercipta di dalam kelompok sosial selama proses interaksi.

8. Kita tidak dapat memahami pengalaman seorang individu dengan mengamati tingkah lakunya belaka. Pengalaman dan pengertian akan berbagai hal harus diketahui pula secara pasti.

\section{B. Kerangka Pikir Penelitian}

Fenomenologi dari Alfred Schutz (1899-1959), dalam The Phenomenologi of Sosial World [1967, p. 7], mengemukakan bahwa orang secara aktif menginterpretasikan pengalamannya dengan memberi tanda dan arti tentang apa yang mereka lihat. Interpretasi merupakan proses aktif dalam menandai dan mengartikan tentang sesuatu yang diamati, seperti bacaan, tindakan atau situasi bahkan pengalaman apapun. Lebih lanjut, Schutz menjelaskan pengalaman inderawi sebenarnya tidak punya arti. Semua itu hanya ada begitu saja; obyek-obyeklah yang bermakna. Semua itu memiliki kegunaan-kegunaan, nama-nama, bagian-bagian, yang berbedabeda dan individu-individu itu memberi tanda tertentu mengenai sesuatu, misalnya menandai orang yang mengajar adalah seorang guru.

Menurut Schutz, cara orang mengkonstruksikan makna dari luar atau dari arus utama pengalaman ialah melalui proses tipifikasi. Dalam hal ini termasuk membentuk penggolongan atau klasifikasi dari pengalaman yang ada. Hubungan- hubungan makna diorganisir secara bersama-sama, juga melalui proses tipifikasi, ke dalam apa yang Schutz namakan "kumpulan pengetahuan" (stock of knowledge). Kumpulan pengetahun bukanlah pengetahuan tentang dunia, melainkan merupakan segala kegunaan-kegunaan praktis dari dunia itu sendiri. Persoalan pokoknya di sini adalah bahwa setelah perkembangan tahap tertentu, kumpulan pengetahuan tersebut yang telah ditipifikasikan, yang terdiri dari dunia saja, juga dimiliki bersama- sama orang lain. Setiap orang sama-sama memiliki pikiran/akal sehat, dunia yang diterima secara begitu saja, yang oleh Schutz (mengikuti Husserl) menyebutnya sebagai "live world", yang merupakan dasar dari semua aktivitasaktivitas sosial. Kemudian disusun dan mengubahnya dalam interaksi sosial lalu menurunkannya dari generasi ke generasi melalui proses sosialisasi yang dilakukan.

Menurut Schutz, fenomenologi adalah studi tentang pengetahuan yang datang dari kesadaran atau cara kita memahami sebuah obyek atau peristiwa melalui pengalaman sadar tentang obyek atau peristiwa tersebut. Sebuah fenomena adalah penampilan sebuah obyek, peristiwa atau kondisi dalam persepsi seseorang, jadi bersifat subjektif. Bagi Shultz dan pemahaman kaum fenomenologis, tugas utama analisis fenomenologis adalah merekonstruksi dunia kehidupan manusia "sebenarnya" dalam bentuk yang mereka sendiri alami. Realitas dunia tersebut bersifat intersubjektif dalam arti bahwa sebagai anggota masyarakat berbagi persepsi dasar mengenai dunia yang mereka internalisasikan melalui sosialisasi dan memungkinkan mereka melakukan interaksi [Mulyana, 2008, p. 63]. 
Dalam konteks fenomenologis, perempuan pelaku pernikahan kembali sesudah perceraian adalah aktor yang melakukan tindakan sosial. Pada aktor tersebut juga memiliki historisitas dan dapat dilihat dalam bentuk yang alami. Teori lain yang mendukung kajian ini adalah Teori Interaksi Simbolik (George Herbert Mead dan Herbert Blumer). Para ahli perspektif interaksionisme simbolik melihat bahwa individu adalah obyek yang bisa secara langsung ditelaah dan dianalisis melalui interaksinya dengan individu yang lain.

Mereka menemukan bahwa individu-individu tersebut berinteraksi dengan menggunakan simbol-simbol, yang di dalamnya berisi tanda- tanda, isyarat dan kata-kata. Simbol atau lambang adalah sesuatu yang digunakan untuk menunjuk sesuatu lainnya, berdasarkan kesepakatan sekelompok orang. Lambang meliputi kata-kata (pesan verbal), perilaku nonverbal, dan objek yang disepakati bersama [Mulyana, 2008, p. 84].

Di dalam bukunya "Symbolic Interactionism; Perspective, and Method," [1986, p. 2], Herbert Blumer, menegaskan bahwa ada tiga asumsi yang mendasari tindakan manusia. Tiga asumsi tersebut adalah sebagai berikut: (1). Human being act to ward things on the basic of the meaning that the things have for them, (2). The meaning of the things arises out of the social interaction one with one's fellow; (3). The meaning of things are handled in and modified through an interpretative process used by the person in dealing with the thing he encounters [Turner \& Lynn, 2010, p. 111].

Dari pendapat tersebut, dapat dijelaskan sebagai berikut, Pertama, bahwa manusia itu bertindak terhadap sesuatu (apakah itu benda, kejadian, maupun fenomena tertentu) atas makna yang dimiliki oleh benda, kejadian, atau fenomena itu bagi mereka. Individu merespon suatu situasi simbolik. Mereka merespon lingkungan, termasuk objek fisik (benda) dan objek sosial (perilaku manusia) berdasarkan makna yang dikandung komponen tersebut bagi mereka.

Kedua, makna tadi diberikan oleh manusia sebagai hasil interaksi dengan sesamanya. Jadi, makna tadi tidak inherent, tidak terlekat pada benda ataupun fenomenanya itu sendiri, melainkan tergantung pada orang-orang yang terlibat dalam interaksi itu. Makna dinegosiasikan melalui penggunaan bahasa. Negosiasi itu dimungkinkan karena manusia mampu menamai segala sesuatu, bukan hanya objek fisik, tindakan, atau peristiwa (bahkan tanpa kehadiran objek fisik, tindakan, atau peristiwa itu) namun juga gagasan yang abstrak. Akan tetapi, nama atau simbol yang digunakan untuk menandai objek, tindakan, peristiwa, atau gagasan itu bersifat arbitrer (sembarang). Melalui penggunaan simbol itulah manusia dapat berbagi pengalaman dan pengetahuan tentang dunia.

Ketiga, makna tadi ditangani dan dimodifikasi melalui proses interpretasi dalam rangka menghadapi fenomena tertentu lainnya. Makna yang diinterpretasikan individu dapat berubah dari waktu ke waktu, sejalan dengan perubahan situasi yang ditemukan dalam interaksi sosial. Perubahan interpretasi dimungkinkan karena individu dapat melakukan proses mental, yakni berkomunikasi dengan dirinya sendiri.

Aplikasi teori tersebut dalam penelitian ini adalah bahwa perempuan yang melakukan pernikahan kembali sesudah bercerai, berinteraksi dengan menggunakan simbol-simbol yang di dalamnya berisi tanda-tanda, isyarat dan kata-kata dalam memaknai realitas keputusan menikah lagi. Berikut adalah gambar alur pemikiran penelitian ini : 
Gambar 1.

Kerangka Pikir Penelitian

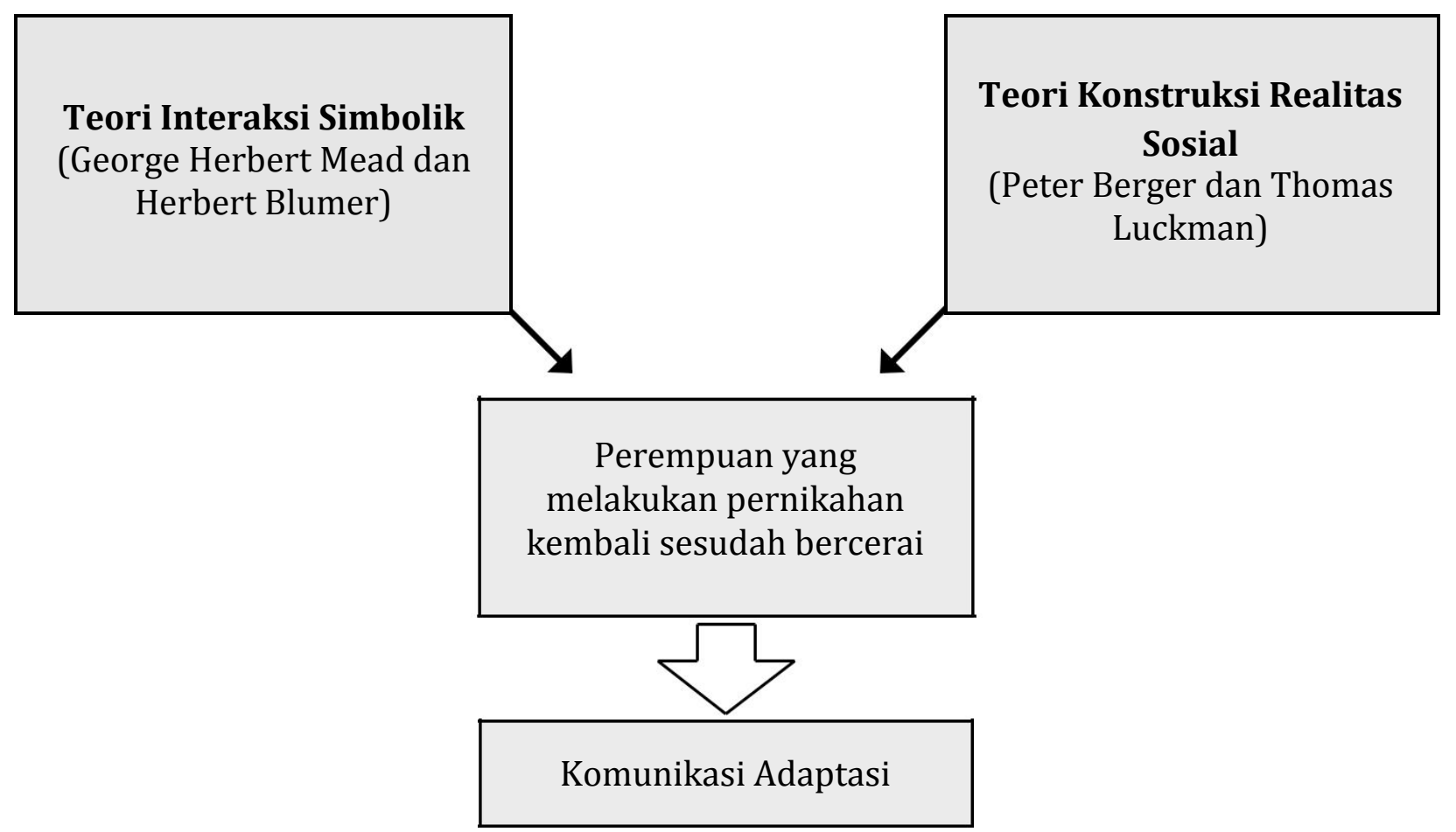

Dari gambar 1, alur kerangka pemikiran tersebut dapat dijelaskan bahwa teori Tindakan Sosial dari Max Weber memayungi teori Interaksi Simbolik (George Herbert Mead dan Herbert Blumer) dan Teori Konstruksi Realitas Sosial (Peter Berger dan Thomas Luckman). Teori Interaksi Simbolik melihat individu-indvidu berinteraksi dengan menggunakan simbol-simbol yang didalamnya berisi tanda-tanda, isyarat dan kata-kata dalam memaknai pengalamannya sendiri termasuk ketika melakukan komunikasi dengan anggota keluarga yang lain misalnya dengan pasangan baru dan keluarga besarnya. Sedangkan Teori Konstruksi Realitas Sosial menggali dan membentuk konstruksi realitas sosial dengan memberi tanda dan arti tentang apa yang mereka alami dalam hal ini adalah perempuan yang melakukan pernikahan kembali sesudah bercerai.

\section{METODE PENELITIAN}

\section{A. Paradigma Penelitian}

Sebagai metode penelitian, fenomenologi sering dikenal sebagai metode deskriptif kualitatif yang digunakan pada paradigma interpretif. Sesuai dengan asumsi ontologis yang ada dalam paradigma interpretif, peneliti yang menggunakan metode ini akan memperlakukan realitas sebagai konstruksi sosial kebenaran. Realitas juga dipandang sebagai sesuatu yang sifatnya relatif, yaitu sesuai dengan konteks spesifik yang dinilai relevan oleh para aktor sosial. Secara epistemologis, ada interaksi antara peneliti dan subjek yang diteliti. Sementara itu dari sisi aksiologis, peneliti akan memperlakukan nilai, etika, dan pilihan moral sebagai bagian integral dari penelitian. Peneliti merupakan fasilitator yang menjembatani keragaman subyektivitas pelaku sosial dalam rangka merekonstruksi realitas sosial. Dalam proses penelitiannya, peneliti akan menempatkan empati dan interaksi dialektis antara peneliti dan subjek penelitiannya. 
Sejalan dengan asumsi-asumsi filosofis tersebut, maka sebagai metode penelitian, fenomenologi adalah cara membangun verstehen (pemahaman) tentang realitas. Verstehen ini dibangun dari sudut pandang para aktor sosial yang mengalami peristiwa dalam kehidupannya. Dalam mencapai verstehen ada aktivitas interpretasi atau pemaknaan. Verstehen yang dicapai dalam tataran personal merupakan konstruksi personal realitas atau konstruksi subyektif. Tugas peneliti kemudian adalah melakukan deskripsi struktural guna mendapatkan konstruksi sosial realitas. Dalam konteks ini ada upaya untuk intersubyektifikasi, yakni upaya untuk melakukan sintesis atau penggabungan dari konstruksi subyektif. Pada tahap ini ada interaksi antara peneliti dan yang diteliti.

Sebagai metode penelitian, fenomenologi menerapkan authenticity sebagai kriteria untuk menilai kualittas penelitian. Authenticity atau keaslian berarti ada upaya meyajikan bukti yang terkait dengan keterbukaan, kejujuran, dan laporan seimbang tentang kehidupan sosial dari sudut pandang mereka yang tinggal dalam kehidupan tersebut sehari-hari. Ini artinya, peneliti berupaya untuk menyajikan potret tentang realitas yang ditelitinya dengan paparan kutipankutipan wawancara menyertai setiap interpretasi yang dibuat peneliti.

Fenomenologi erat dengan keyakinan yang disebut sebagai the perspective from within atau the native's point of view. Dalam pandangan fenomenologi pada dasarnya manusia adalah makhluk yang menciptakan makna bagi dunianya. Melalui aktivitas penciptaan makna, manusia sebagai subjek penelitian aktif membangun pengetahuan tentang dunianya. Dengan keyakinan ini, maka peneliti fenomenologi dalam mencari pemahaman akan mengakui pandangan dari dalam (the perspective from within), yakni pandangan para aktor sosial yang mengalami peristiwa sehari-hari di tempat penelitian (the native's point of view). Sebagai konsekuensi dari pengakuan atas the native's point of view adalah penggunaan prinsip emik dalam penelitian fenomenologi. Artinya, penekanan pada perspektif dan konsep-konsep yang berkembang dari dalam sebagai bentuk kearifan lokal atau pemahaman para anggota sebuah sistem sosial.

\section{B. Subjek Penelitian dan Aksesnya}

Untuk sebuah studi fenomenologis, kriteria informan yang baik adalah: all individuals studied represent people who have experienced the phenomenon". Jadi lebih tepat memilih informan yang benar-benar mengalami pernikahan kembali sesudah bercerai yang karena pengalamannya dia mampu mengartikulasikan pengalaman dan pandangannya tentang sesuatu yang dipertanyakan.

Pemilihan subjek penelitian harus disesuaikan dengan perumusan tujuan yang sudah dilakukan atau dengan kata lain peneliti harus mencari dan mewawancarai subjek yang sesuai dengan tujuan penelitian. Hal ini sejalan dengan pengambilan sampel bertujuan (purposive sampling). Purposive sampling termasuk satu dari beberapa jenis pengambilan sampel non probabilitas (non probability sampling) yang biasanya digunakan dalam penelitian kualitatif. Disebut probabilitas karena tidak bertujuan untuk menggeneralisasikan temuan penelitian. Jadi sifat penelitiannya ideografis atau kasuistik. Peneliti naturalistik memang harus hati-hati untuk mentransfer temuannya dari kasus satu orang atau satu kelompok ke kasus satu orang atau kasus satu kelompok lainnya.

Pada sampel bertujuan seperti ini, jumlah sampel ditentukan oleh pertimbanganpertimbangan informasi yang diperlukan. Jika maksudnya memperluas informasi, dan jika 
tidak ada lagi informasi yang dijaring, maka penarikan sampel pun sudah dapat diakhiri. Jadi, kuncinya di sini adalah jika sudah mulai terjadi pengulangan informasi, maka penarikan sampel sudah harus dihentikan.

Dengan demikian maka subjek dalam penelitian ini adalah lima orang perempuan pelaku pernikahan kembali sesudah bercerai. Keakraban yang sudah terjalin dengan subjek penelitian memudahkan peneliti memperoleh informasi yang dibutuhkan terkait dengan masalah penelitian. Demikian pula dengan subjek penelitian menunjukkan kesediaannya untuk memberikan informasi yang dibutuhkan penelitian.

\section{Teknik Pengumpulan Data}

Teknik pengumpulan data berupa in-depth interview atau wawancara mendalam. Tiga model wawancara yaitu terstruktur, terfokus, atau semi terstruktur, dan tak terstruktur. Wawancara mendalam mencakup model terfokus atau semi terstruktur, dan tak terstruktur. Dilihat dari sifat kealamiahannya, wawancara tak terstruktur lebih bersifat alamiah atau natural dan jenis wawancara inilah yang digunakan dalam penelitian ini. Adapun instrumen yang dipakai dalam teknik ini adalah diri peneliti atau pewawancara sendiri. Alat bantu yang digunakan berupa interview guide atau pedoman wawancara. Pedoman wawancara adalah daftar tentang isu-isu yang akan diungkap oleh peneliti. Wawancara mendalam dilakukan pada sejumlah informan dengan pendalaman informasi sesuai dengan kebutuhan untuk menjawab masalah penelitian [Mulyana, 2007, p. 78].

Wawancara mendalam merupakan teknik pengumpulan data dengan cara pertukaran verbal tatap muka yang dilakukan oleh seorang pewawancara terhadap subyek penelitian. Pertemuan tatap muka dilakukan berulang antara peneliti dan subjek penelitian. wawancara mendalam dengan model terfokus atau semi terstruktur mengharuskan peneliti untuk berbekal topik yang dapat menjadi panduan wawancara. Panduan ini berupa skedul wawancara atau disebut pula sebagai interview guide (pedoman wawancara). Pedoman wawancara dikembangkan di seputar daftar topik yang dimiliki oleh peneliti, meskipun untuk itu tidak perlu keteraturan pertanyaan yang sifatnya fix atau tidak dapat dirubah. Ini artinya bahwa muatan wawancara terfokus pada isu-isu yang menjadi inti dari pertanyaan penelitian (rumusan masalah). Namun jenis pertanyaan dan diskusi tetap memberikan ruang terbuka pada fleksibilitas.

Selain itu, peneliti juga melakukan studi pustaka yang digunakan untuk mencari konsepkonsep dan landasan teori yang digunakan, baik dari buku, diktat, jurnal, majalah, surat kabar, internet dan sebagainya. Dokumentasi juga digunakan untuk mengetahui dokumendokumen yang ada relevansinya dengan permasalahan yang diteliti. Data dapat diperoleh melalui penelusuran terhadap artikel-artikel yang berkaitan dengan topik penelitian.

\section{Prosedur Pencatatan Data}

Dalam pengumpulan data melalui wawancara ditempuh tahap-tahap atau prosedur yang mencakup bertanya, menginterpretasi, menyimpulkan, memeriksa, dan verifikasi. Peneliti mengajukan pertanyaan, ketika subyek penelitian memberikan jawabannya, peneliti mendengarkan secara analitik. Setelah itu peneliti menginterpretasikan, membuat kesimpulan, dan membuat catatan pemeriksaan guna melakukan verifikasi, baik berupa probing atau crosscheck. 
Tahap awal dalam wawancara mendalam adalah mengajukan pertanyaan kepada subyek penelitian. Di tahap ini terdapat aktivitas funneling. Aktivitas ini mengacu pada sebuah proses bertanya yang mengharuskan pewawancara mengontrol aliran dan tipe informasi. Wawancara dimulai dengan pertanyaan-pertanyaan yang bersifat umum atau tentang data biografi subyek penelitian, pandanganya tentang sesuatu, dan kemudian masuk pada topik inti.

Setelah peneliti memperoleh data, tahap berikutnya adalah interpretasi. Dapat dikatakan bahwa aktivitas interpretasi pada metode fenomenologi merupakan implikasi atas asumsi keaktifan manusia menginterpretasikan pengalamannya. Ada dua tataran interpretasi, yaitu pertama, untuk memperoleh makna subyektif yang menghasilkan konstruksi personal atau konstruksi individual, disebut pula sebagai deskripsi subyektif atau deskripsi tekstural. Kedua, interpretasi untuk mendapatkan makna konsensus atau konstruksi sosial. Tahap ini disebut sebagai deskripsi intersubyektif atau deskripsi struktural.

Dari interpretasi ini peneliti menyimpulkan dan melakukan pemeriksaan untuk verifikasi. Tahap verifikasi sendiri berwujud probing dan cross-check. Baik aktivitas probing maupun cross-check dimulai dengan menyusun pertanyaan. Pertanyaan probing ditujukan untuk mendapatkan informasi yang lebih dari pertanyaan asli. Pertanyaan asli adalah pertanyaan awal yang memperkenalkan topik. Pertanyaan probing dikembangkan dari jawaban terhadap pertanyaan asli. Pertanyaan pendalaman diajukan pada subjek penelitian yang sama. Sementara itu, pertanyaan cross-check digunakan untuk melihat kejujuran informan dalam mengungkap diri sendiri dan pengalamannya. Dalam konteks ini, pertanyaan yang sama diajukan pada informan yang berbeda. Aktivitas ini pada dasarnya merupakan pemenuhan atas prinsip dialektis yang terkait dengan asumsi metodologis paradigma konstruktivisme. Secara teknis, pengumpulan data dengan teknik ini dapat dibantu dengan alat-alat rekam, seperti tape recorder, voice recorder, dan sejenisnya. Namun guna menghindari ketergantungan teknologi yang mungkin bisa saja terjadi kesalahan teknis, seperti tidak terekamnya suara, maka peneliti dianjurkan untuk membuat catatan wawancara, sehingga tetap memiliki data yang tidak hanya berdasar ingatan. Pada observasi juga dilakukan aktivitas pencatatan kejadian-kejadian yang berkaitan dengan isu yang menjadi pokok dalam penelitian.

\section{E. Teknik Analisis Data}

Data dalam penelitian ini menggunakan analisis data model interaktif Miles dan Huberman [Islami, p. 2001] yaitu terdapat tiga proses yang berlangsung secara interaktif. Pertama reduksi data, yaitu proses memilih, menfokuskan, menyederhanakan, dan mengabstraksikan data dari berbagai sumber data, misalnya dari catatan lapangan, dokumen, arsip dan sebagainya. Selanjutnya proses mempertegas, memperpendek, membuang yang tidak perlu, menentukan fokus dan mengatur data sehingga kesimpulan bisa dibuat. Kedua, penyajian data, seperti merakit data dan menyajikannya dengan baik supaya lebih mudah dipahami. Penyajian bisa berupa matriks, gambar/skema, jaringan kerja, tabel dan seterusnya. Ketiga, menarik kesimpulan/verifikasi, proses penarikan kesimpulan awal masih belum kuat, terbuka dan skeptis. Kesimpulan akhir dilakukan setelah pengumpulan data berakhir. Verifikasi diperoleh lewat proses negosiasi/konsensus antar subyek, berdiskusi dengan sejawat, memeriksa data antar anggota. 


\section{F. Verifikasi}

Yang pertama kali perlu diperhatikan adalah kredibilitas. Untuk menunjang kredibilitas peneliti, peneliti berusaha membangun rapport dan mempelajari situasi sosial dan budaya di lingkungan partisipan. Peneliti juga melakukan triangulasi dengan berusaha menemukan berbagai sudut pandang lain untuk mengecek kebenaran temuan, seperti buku-buku, jurnal-jurnal, serta metode lain (tidak hanya wawancara namun juga observasi). Lalu dilakukan pula peer debriefing atau peer review. Hasil penelitian diperiksa oleh rekan sejawat yang memiliki pemahaman umum atas penelitian ini. rekan sejawat diharapkan dapat memeriksa persepsi, insight, dan analisis peneliti. Dan peneliti juga melakukan cek anggota (member check). Peneliti datang menemui partisipan yang sudah diambil datanya untuk mengecek kebenaran data dan interpretasi yang dilakukan peneliti.

Berikutnya perlu diperhatikan transferabilitas. Transferabilitas membantu pembaca untuk melihat kemungkinan menerapkannya dalam situasi lain yang mirip. Untuk menunjang transferabilitas perlu dilakukan dua hal. Pertama, deskripsi yang detil. Peneliti kualitatif diharapkan membuat laporan secara detil agar pembaca memiliki lebih banyak peluang untuk mentransfer sendiri temuan peneliti dalam situasi lain yang mirip. Kedua, purposive sampling dengan karakteristik subjek yang jelas. Kemudian dependabilitas penting untuk meyakinkan pembaca bahwa penelitian yang dilakukan cukup konsisten. Untuk mendukung dependabilitas (daya konsistensi), ada satu hal yang penting dilakukan adalah audit eksternal. Peneliti mengajak konsultan atau auditor (yang paham betul metode penelitian kualitatif dan topik penelitian) untuk memeriksa proses dan hasil penelitian. Agar pemeriksaan tidak subjektif, sebaiknya konsultan atau auditor tidak memiliki 'hubungan khusus' dengan peneliti.

Sedangkan konfirmabilitas (daya kenetralan) didukung oleh data mentah hasil pengumpulan data yang meliputi tulisan partisipasn, hasil rekaman wawancara, dan catatan-catatan di lapangan, serta proses analisis yang benar.

\section{HASIL PENELITIAN DAN PEMBAHASAN}

\section{A. Profil Subjek Penelitian}

Subjek pertama (P-1), tinggal di rumah dengan luas tanah $300 \mathrm{~m} 2$ yang ditempatinya sejak awal tahun 2005 bersama kedua anaknya. Wawancara dan observasi dilakukan di kediaman subjek di sebuah lokasi pemukiman yang ramai penduduk. Suasana ketika wawancara di ruang tamu cukup tenang, netral, dan privat, yang mendukung kenyamanan dan kesediaan subjek dalam memberikan informasi mengenai pengalamannya. Suasana di luar rumah yang relatif sepi pun saat itu turut mendukung kelancaran proses wawancara. Ruang tamu berlantai keramik tempat dilaksanakannya wawancara berukuran $3 \times 3 \mathrm{~m}$, bercat coklat muda, dengan meja, sofa, dan beberapa guci tertata rapi. Subjek adalah wanita berusia 48 tahun yang sedang menjalani pernikahan keduanya setelah bercerai dari suami pertama pada tahun 1999 silam. Ia memutuskan untuk menikah lagi 5 tahun kemudian setelah perceraiannya. Dari pernikahan pertamanya, ia dikaruniai seorang putra yang saat ini tinggal terpisah karena telah berkeluarga. Pernikahan keduanya pada tahun 2004 dengan seorang pria yang berstatus sama dengannya yaitu duda anak satu. Pria yang bekerja sebagai guru ini lebih tua 5 tahun darinya. Berbeda dengan suami pertama yang selisih umurnya hanya 2 tahun. Subjek dikaruniai seorang anak perempuan dan seorang anak laki -laki 
yang saat ini masing - masing berusia 7 dan 4 tahun. Subjek bekerja sebagai guru taman kanak-kanak (TK). Sejak lahir subjek yang anak bungsu dari tujuh bersaudara tinggal di rumah orang tua. Saudara kandung subjek setelah menikah meninggalkan rumah, namun tidak demikian dengan subjek. Setelah menikah, ia pun tetap tinggal di rumah itu bersama ayah, ibu, suami, dan seorang anaknya dari pernikahan pertama. Tahun 2004 subjek membeli tanah dan membangun rumah bersama suami keduanya. Kemudian pada awal tahun 2005 subjek menempati rumah barunya di sebuah kawasan pemukiman yang ramai penduduk. Ia merasa nyaman tinggal di lingkungan ini karena beberapa teman lama menjadi tetangganya, dan dengan mereka subjek terlibat beberapa aktivitas, seperti melakukan kegiatan rohani (pengajian).

Subjek kedua (P-2), perempuan kelahiran Bandung pada 12 Oktober 1975 adalah seorang ibu rumah tangga yang juga bekerja di sebuah pabrik tekstil di kota kelahirannya. Pernikahan pertamanya dilakukan pada saat ia berstatus mahasiswa. Demikian pula dengan suami pertamanya saat itu juga berstatus mahasiswa pada sebuah perguruan tinggi swasta di Kota Bandung. Keputusan mereka menikah di usia muda dan keadaan ekonomi belum mapan diambil karena ingin menghindari timbulnya masalah-masalah yang tidak diinginkan oleh keluarga. Pernikahan pertama pada tahun 1997 dikaruniai dua orang anak perempuan yang saat ini masing-masing berusia 14 dan 11 tahun. Prahara rumah tangganya mulai muncul menjelang lahirnya anak kedua. Keputusan untuk bercerai akhirnya diambil setahun kemudian tepatnya pada tahun 2002. Pada tahun yang sama ia berkenalan dengan seorang pria bekerja yang masih lajang. Pria kelahiran 1968 itu akhirnya meminang subjek pada tahun 2003. Pernikahan kedua subjek jalani hingga saat ini dan telah dikaruniai 2 orang anak, perempuan dan laki-laki, yang saat ini masing-masing berusia 8 tahun dan 3 tahun.

Subjek ketiga (P-3), seorang ibu rumah tangga dengan dua orang anak dari hasil pernikahan pertama dan keduanya. Perempuan kelahiran Sukabumi pada tanggal 20 Juni 1982 ini mengarungi bahtera rumah tangga dengan suami pertama selama 5 tahun dan dikaruniai seorang putri yang kini berusia 8 tahun.Tepatnya ia menikah tahun 2002 dan memutuskan untuk bercerai pada tahun 2007. Keputusan menikah lagi diambil subjek tiga tahun setelah perceraian tepatnya tahun 2010 baru dikaruniai seorang putri yang berusia 1 tahun. Suami kedua adalah seorang pria yang bekerja pada dealer motor. Saat ini pasangan suami istri ini menempati sebuah rumah kontrakan yang dekat dari kantor sang suami.

Subjek keempat (P-4) adalah seorang perempuan Jawa yang berprofesi sebagai dokter di sebuah rumah sakit pemerintah di Jakarta. Pernikahan pertama perempuan kelahiran Yogyakarta, 15 April 1966 hanya bertahan tiga tahun. Ajeng mempunyai satu putra yang kini sudah kuliah di sebuah universitas negeri di Depok. Mantan suaminya yang juga seorang dokter di rumah sakit yang sama, telah menikah lagi dengan seorang perawat, tak lama setelah mereka bercerai.

P-4 cukup lama menjanda karena merasa sulit menghilangkan trauma pasca perceraian, sehingga sangat lama menutup diri dan menata hati. Namun akhirnya P-4 membina biduk rumah tangga lagi empat tahun yang lalu dengan seorang duda yang memiliki satu anak perempuan yang seumur dengan putra P-4. Suami kedua P-4 bekerja sebagai konsultan dan trainer di beberapa perusahaan. Saat ini mereka tinggal bersama anak-anak mereka di perumahan mewah di BSD.

Subjek kelima (P-5) kelahiran Manado 27 Agustus 1967 adalah seorang dosen di sebuah 
universitas swasta di Jakarta. Pernikahan pertamanya dilakukan tanpa restu orangtua, dan ternyata mantan suami sangat temperamental, pencemburu, dan sering melakukan KDRT. Salah satu alasan keretakan rumah tangga mereka adalah karena P-5 tak kunjung hamil.

Saat bercerai P-5 tak mempunyai anak, sehingga berstatus janda tanpa anak. Setelah sembilan tahun menjanda, akhirnya P-5 menemukan pelabuhan hatinya, seorang duda yang mempunyai dua orang anak. Pertemuan terjadi saat mereka menghadiri sebuah seminar. Saat ini P-5 tengah hamil muda. Suami keduanya bekerja sebagai reporter sebuah televisi swasta di Jakarta, dan mempunyai kedudukan yang cukup penting.

\section{B. Konstruksi Realitas Sosial Perempuan Pelaku Pernikahan Kembali Sesudah Bercerai}

Psikologi humanistik menyebutkan bahwa "humanistic psychology is not just the study of 'human being'; it is a commitment to 'human becoming". Menurut pandangan kaum humanistik bahwa hakekat kemanusiaan adalah bukan sekedar human being tetapi human becoming. Manusia menjadi lebih bermakna jika dirinya dipandang sebagai "menjadi manusia" (human becoming) bukan hanya atas dasar "kemanusiaannya" (human being) saja. Sebuah "proses yang menjadi" itulah bagian dari hakikat diri manusia.

Sebuah proses adalah sebuah pilihan. Dengan mengamati "proses", kita akan dapat lebih memahami mengapa banyak orang yang memutuskan untuk menikah kembali setelah mengalami kegagalan pada pernikahan pertamanya. Keputusan tersebut bagi sebagian orang bukan hal yang mudah. Demikian pula dengan anggapan dari masyarakat yang menilai keputusan untuk segera menikah pasca perceraian sebagai sebuah perilaku negatif.

Sejalan dengan pandangan humanisme, peneliti akan mengungkapkan bagaimana hakikat diri perempuan pelaku remarriage pasca perceraian apabila proses pengambilan keputusan tersebut dapat kita telusuri. Bagaimana sebuah proses terjadi yang dialami perempuanperempuan tersebut sehingga mereka memutuskan menikah lagi akan membawa kita pada penjelasan tentang latar belakang atau alasan dan motif (atau account) mereka.

Pernikahan adalah amanat Illahi agar manusia hidup dalam keseimbangan dan mendapatkan kebahagiaan, ketenteraman, ketenangan lahir maupun batin. Pernikahan merupakan amanat Tuhan agar manusia berkembang biak dengan cara yang halal, sehingga terbentuk generasi baru kemanusiaan yang lebih baik dan lebih berkualitas untuk meneruskan pengelolaan alam semesta.

Pernikahan kedua memiliki dua misi yaitu membina hubungan yang dekat dengan pasangan sekaligus menjalin kedekatan emosional dengan anak, baik antara orangtua maupun antara anak-anak mereka (anak tiri dan anak kandung). Dengan demikian kualitas kepribadian kedua orang tua menentukan apakah pernikahan kedua akan dapat dijalani dengan mulus atau tidak.

Oleh karena itu, niat awal dari pernikahan kedua menjadi sangat penting. Orang tua yang memutuskan menikah kembali harus memiliki pribadi yang matang secara emosi, di samping matang secara finansial. Kemandirian finansial memang diperlukan pada pernikahan ke dua karena kebutuhan keluarga semakin beragam. Namun kematangan diri orang tua akan lebih banyak membantu dalam menyesuaikan diri dengan peran baru di pernikahan ke dua.

Terdapat beberapa alasan menikah lagi setelah perceraian sehingga menjadi keputusan 
terbaik yang perlu ditempuh. Keputusan untuk menikah lagi memiliki banyak keuntungan, baik bagi perkembangan anak maupun orang tua. Pernikahan kedua bisa membuat orang tua merasa lebih tenang karena memiliki pasangan hidup sebagai tempat berdiskusi mengenai berbagai hal. Orang tua yang tadinya merasa terbebani karena harus memutuskan segalanya sendiri, kini bisa membahas masalah-masalahnya dan mendapat masukan solusi dari pasangan yang baru. Hal ini tentu berpengaruh terhadap tingkat stress orang tua.

Beberapa alasan yang mendorong individu untuk menikah lagi antara lain untuk mendapatkan cinta dan persahabatan, pemenuhan kebutuhan biologis, faktor kebutuhan ekonomi/ keuangan, etika, moral, dan norma sosial, faktor pemeliharaan atau pendidikan anak serta untuk memperoleh status sosial.

Dari segi pemenuhan faktor biologis, menikah lagi dianggap sebagai jalan terbaik untuk menyalurkan kebutuhan seksual secara sah dengan pasangan hidup yang baru apalagi untuk individu yang masih berada dalam usia reproduktif. Dengan menikah lagi, individu dapat memenuhi kebutuhan biologisnya dengan tetap memenuhi norma sosial.

Hal tersebut ditegaskan oleh subjek penelitian, P-1 yang memiliki pengalaman menikah di usia 20 tahun untuk pernikahan pertamanya. Berikut penuturannya:

"banyak orang kalau ditanya alasannya menikah lagi alasan ini alasan itu,Mbak. Kalau Saya mah...karena Saya tidak ingin terjerumus ke dalam hubungan yang dilarang agama karena tidak bisa menahan hasrat yang satu itu. Seks...maksud Saya. Saya masih muda Mbak...untuk urusan yang satu itu Saya pikir bukan hal yang mesti kita tutup-tutupi. Saya pikir itu manusiawi banget, dari pada kita salah bergaul lebih baik kita menikah lagi untuk menyalurkannya secara syah dengan pasangan kita. Gak dosa kan, Mbak". (Wawancara, 11 Oktober 2015).

Selain itu seseorang memutuskan untuk menikah lagi setelah perceraian karena dihadapkan pada masalah dukungan sosial. Kehidupan sosial mereka juga mengalami perubahan. Subjek yang bernama P-2 yang kini berusia 37 tahun mengalami masalah dengan dukungan sosial setelah perceraiannya pada tahun 1999 silam. Masa menjanda ia jalani selama 5 tahun hingga ia memutuskan menikah pada tahun 2004 lalu. Berikut alasannya :

"Saya bertahan dengan pernikahan pertama Saya selama 10 tahun. Setelah perceraian, Saya merasakan banyak yang berubah dalam hidup Saya. Salah satunya adalah hubungan Saya dengan teman-teman dan keluarga yang statusnya menikah. Ketika Saya baru bercerai, mereka selalu ada untuk Saya. Tapi lama kelamaan Saya rasakan mereka semakin menjauh, Mbak. Mereka sudah tidak mengajak Saya lagi dalam arisan keluarga, teman-teman Saya yang masih utuh rumah tangganya juga sudah jarang ngajak ngumpul. Saya rasa mereka takut kalau suaminya dekat-dekat dengan janda seperti Saya. Benar, lho Mbak Saya gak tahan dengan anggapan negatif itu. Kadang kalau Saya sedang jalan sendiri, Saya melihat tatapan yang kurang bagus dari orang-orang. Satu hal yang juga membuat Saya stress dan tertekan. Orang-orang selalu bertanya, kapan nikah lagi. Bosan atuh Mbak dengarnya" (Wawancara, 8 Oktober 2015)

Seseorang juga memilih untuk menikah lagi untuk memenuhi kebutuhan ekonomi baik untuk diri sendiri maupun untuk anak-anaknya. Selain itu, bagi individu yang memiliki anak dari pernikahan sebelumnya akan mendapatkan bantuan dalam mengurus, memelihara ataupun 
mendidik anak-anaknya. Hal ini diungkapkan oleh subjek P-3 yang memiliki seorang anak dari pernikahan pertamanya. Pekerjaannya yang hanya serabutan, misalnya menjadi tukang cuci dan setrika sambil menjadi pengasuh anak bagi tetangganya yang kebetulan wanita karir mendorongnya untuk menikah lagi. Alasan tersebut ia kemukakan seperti berikut:

"Saya memang punya anak satu, Mbak. Mungkin orang berpikir anak satu gak bikin susah. Iya...kalau ibunya punya kerja tetap. Gimana kalau kayak Saya? Kerjaan tidak jelas, penghasilan juga gak tetap pasti susahlah, Mbak. Tidak muluk-muluk yang Saya inginkan dari pernikahan berikutnya, setidaknya ada teman berbagi dalam hal mencari makan. Tidak perlu pegawai negeri yang penting ada kerjanya dan tulus membiayai Saya dan anak Saya. Terus terang, Mbak. Mantan suami Saya yang pertama sudah tidak ada kabar beritanya lagi. Mana dia ingat anaknya, Mbak." (Wawancara, 11 Oktober 2015)

Berdasarkan kutipan wawancara dengan subjek tersebut menunjukkan bahwa terdapat kesulitan yang dihadapi seseorang setelah terjadi perceraian. Secara finansial perceraian menyebabkan kesulitan ekonomi, dalam hal ini pendapatan dan keuangan yang terbatas. Tidak hadirnya suami sebagai kepala keluarga dan pencari nafkah bagi keluarga, seorang perempuan harus mampu mengambil keputusan dan bertanggung jawab sendiri, termasuk mencari nafkah bagi dirinya dan juga anak-anaknya.

Berbeda dengan penuturan P4 yang bekerja sebagai seorang dosen, sebagai berikut :

"Saya tak punya masalah dengan masalah finansial, Mbak. Karena Saya bekerja, dan gaji saya sangat cukup untuk menghidupi saya seorang diri, bahkan Saya sering juga membantu orangtua Saya, walau mereka sudah berkecukupan. Makanya awalnya Saya ragu untuk menikah lagi, apalagi saya pernah punya pengalaman buruk, Saya takut dikasari lagi" (Wawancara, 17 Oktober 2015).

Pengalaman serupa dituturkan pula oleh P-4 :

"Pekerjaan Saya menuntut konsentrasi penuh, sehingga tak terpikir untuk menikah lagi. Apalagi ada putra semata wayang yang selalu mensupport Saya. Alhamdullilah Alloh selalu membuka pintu rezeki buat saya, InsyaAlloh tak pernah ada kesulitan dengan masalalah uang. Mantan suami juga masih sering memberi uang jajan untuk anak, walau tak banyak" (Wawancara, 19 Oktober 2015).

Dari penuturan P-4 dan P-5, karena mereka adalah wanita karir yang masing-masing memiliki pekerjaan profesional, maka tak ada kendala finansial bagi mereka. Namun, keputusan untuk menikah lagi setelah perceraian seringkali berbenturan dengan pengalaman pahit kegagalan perkawinan sebelumnya. Hal senada diungkapkan oleh subjek penelitian, P-1 berikut :

"Selama 5 tahun saya menjanda, tidak ada pikiran untuk menikah lagi, karena pengalaman yang tidak menyenangkan dengan perkawinan saya sebelumnya. Tapi anak sudah besar, Saya memikirkan hidup tua nanti. Saya juga berpikiran kalo nanti anak perempuan Saya menikah, Saya ingin ada bapak yang menjadi walinya walaupun ayah kandungnya masih hidup ato sudah mati, kami tak menganggapnya lagi." (Wawancara, 8 Oktober 2015) 
Dari kutipan cerita di atas, dapat dilihat bahwa seorang wanita yang telah bercerai pada awalnya merasa takut untuk menikah lagi. Namun seiring dengan waktu, wanita bercerai ini memiliki keinginan untuk menikah lagi dengan tujuan untuk kebahagiaan dirinya dan memikirkan wali untuk anaknya jika kelak anaknya menikah.

Selain itu, setelah perceraian individu akan mulai menyadari bahwa kini mereka hidup seorang diri dan kesepian. Hidup seorang diri, dalam arti, dulu semua hal dikerjakan dan dibahas bersama pasangan, namun setelah perceraian semua hal dikerjakan dan dipikirkan sendiri. Hal ini sesuai dengan penuturan salah seorang wanita bercerai yang menjadi subjek dalam penelitian ini. P-3, perempuan berusia 30 tahun ini mengungkapkan keinginannya untuk menikah lagi karena membutuhkan pasangan untuk menjalani hidup seperti dalam kutipan wawancara di bawah ini:

"Saat itu keinginan menikah lagi muncul setelah Saya menjanda selama 3 tahun. Awalnya Saya merasa kuat hidup sendiri tapi lama kelamaan perasaan kesepian itu terus mendera Saya apalagi kalau mendapati diri sedang sakit, rasa ingin punya teman di saat seperti itu semakin memuncak. Akhirnya Saya memutuskan ingin menikah lagi karena Saya sadar bahwa hidup ini terlalu berat untuk dijalani sendirian. Saya butuh seseorang yang bisa saling mendukung dalam segi spiritual dan material, Saya pengen nikah lagi karena Saya butuh menyayangi seseorang dan butuh untuk disayangi, Mbak. Saat itu gak ada target kapan waktunya, Saya pasrahkan saja sama Allah”. (Wawancara, 11 Oktober 2015)

Banyak orang yang menyimpulkan bahwa perkawinan merupakan sumber kebahagiaan dan pencapaian tertinggi kehidupan. Namun perlu dipahami bahwa sebenarnya kebahagiaan dalam perkawinan tergantung dari pihak-pihak yang terlibat di dalamnya (dalam hal ini suami dan isteri) dan bagaimana mereka berinteraksi satu sama lain dalam sebuah ikatan yang permanen. Pernikahan adalah anugerah dari Tuhan yang diberikan kepada manusia. Karena itulah, tidak seharusnya seseorang memutuskan untuk menikah dalam kegelisahan atau ketidaktenangan batin.

Hal tersebut senada dengan yang diungkapkan oleh salah seorang subjek dalam penelitian ini. P-2 adalah seorang perempuan yang menjalani mahligai pernikahan pertama selama 5 tahun hingga terjadi perceraian di tahun 2002. Tidak perlu waktu lama baginya untuk memutuskan menikah lagi setahun kemudian dengan harapan ingin menjalani kehidupan yang lebih bahagia seperti penuturannya berikut :

"Saya kira tidak ada seorang pun di dunia ini yang tidak ingin bahagia, kan Mbak. Kegagalan rumah tangga yang pertama meninggalkan duka bagi Saya dan anak-anak. Tapi Saya tidak mau terus larut dalam duka itu. Saya juga berhak bahagia. Menikah lagi dengan pasangan baru Saya pikir menjadi jalan buat Saya untuk bahagia. Awalnya Saya sempat ragu pada diri Saya apalagi jodoh kedua itu datang begitu cepat, hanya setahun saja Mbak Saya menyandang status janda". (Wawancara, Oktober 2015)

P-5 yang pada pernikahan pertamanya sering mengalami perlakuan buruk (KDRT) yang dilakukan oleh mantan suaminya, akhirnya memutuskan menikah lagi karena ingin mempunyai teman untuk tempat berbagi. Berikut penuturannya :

"Saya sebenarnya takut ketika akan menikah lagi. Saya menganggap lelaki itu semua sama, suka memukul dan suka menindas. Tapi saya berfikir rasional saja. Saya tak 
memiliki anak, di hari tua nanti Saya ingin punya teman berbagi suka duka. Syukurlah, akhirnya Tuhan malah memberi Saya satu paket, suami plus dua anak" (Wawancara, Oktober 2015).

Namun pendapat P-4 agak berbeda dengan P-5, dengan malu-malu P-4 menyatakan menikah lagi terutama untuk status, walaupun P-4 cukup lama menutup diri dan hatinya.

\begin{abstract}
“Jujur saja Mbak...he...he...aku malu nih ngomongnya. Alasan Saya menikah lagi karena merasa tidak nyaman terus-menerus menyandang status janda. Gak enak lo Mbak jadi janda. Walau kita berperilaku baik, tetap saja orang memandang negatif. Apalagi Saya bekerja satu Rumah Sakit dengan mantan suami, jadi masih sering bertemu. Saya jadi risih, Mbak. Alhamdulillah setelah Saya menikah lagi, Saya jadi lebih percaya diri, terutama bila harus bekerja satu tim dengan mantan suami yang juga sudah lama menikah lagi" (Wawancara, 19 Oktober 2015)
\end{abstract}

Berdasarkan jawaban subjek penelitian atas apa alasan dan motif pertama mereka mendorong menikah lagi setelah perceraian, maka peneliti dapat membahasnya berdasarkan pendapat dari Alfred Schutz. Schutz setuju dengan pemikiran Weber tentang pengalaman dan perilaku manusia (human being) dalam dunia sosial keseharian sebagai realitas yang bermakna secara sosial (socially meaningful reality). Schutz menyebut manusia yang berperilaku tersebut sebagai aktor. Ketika seseorang melihat apa yang dikatakan atau diperbuat aktor, dia akan memahami (understand) makna dari tindakan tersebut. Dalam dunia sosial hal demikian disebut sebagai sebuah "realitas interpretif" (interpretive reality).

Selain makna intersubjektif, dunia sosial menurut Schutz harus dilihat secara historis. Oleh karenanya Schutz menyimpulkan bahwa tindakan sosial adalah tindakan yang berorientasi pada perilaku orang atau orang lain pada masa lalu, sekarang dan akan datang.

Schutz selanjutnya menjelaskan bahwa melihat ke depan pada masa yang akan datang (looking forward into the future) merupakan hal yang esensial bagi konsep tindakan atau action. Tindakan adalah perilaku yang diarahkan untuk mewujudkan tujuan pada masa datang yang telah ditetapkan (determinate). Kalimat tersebut sebenarnya mengandung makna juga bahwa seseorang memiliki masa lalu (pastness). Dengan demikian tujuan tindakan memiliki elemen ke masa depan (futurity) dan elemen ke masa lalu (pastness).

Proyek yang dimaksudkan oleh Schutz dari tindakan merupakan sebuah makna yang rumit atau makna yang kontekstual. Oleh karenanya untuk menggambarkan keseluruhan tindakan seseorang perlu diberi fase. Dua fase yang diusulkan oleh Schutz diberi nama account atau motif menurut Alfred Schutz yang member identitas dua fase, yaitu in-orderto-motive (Um-zu-Motiv) yang merujuk pada masa yang akan datang dan tindakan because-motive (Weil-Motiv) yang merujuk pada masa lalu.

Hasil wawancara dengan kelima subjek penelitian sebelumnya menunjukkan bahwa mereka menganggap bahwa menikah lagi sebagai solusi untuk menyesuaikan diri setelah perceraian dan segala manfaat atau hal yang dirasakan dengan menikah lagi menumbuhkan harapan. Harapan muncul karena mereka menginginkan suatu perubahan yang lebih baik. Individu yang pernah bercerai, tanpa melihat bagaimana perceraian yang dialaminya tentu memiliki harapan untuk bisa membangun pernikahan yang lebih baik dari sebelumnya. 
Keinginan untuk menikah lagi dengan alasan dan motif tertentu juga dapat menjadi dasar untuk perubahan kehidupannya ke arah yang lebih baik. Harapan adalah sesuatu yang dapat dibentuk dan dapat digunakan sebagai langkah untuk perubahan. Perubahan yang menguntungkan dapat mendorong individu mencapai hidup yang lebih baik.

Harapan di sini peneliti identikkan dengan in-order -motif yang merujuk kepada masa yang akan datang. Subjek dalam penelitian ini menunjukkan individu yang memiliki harapan. Setiap individu memiliki kemampuan untuk membentuk harapan yang berperan mengarahkan tingkah laku dan mencakup dua aspek, yaitu tindakan antisipasi atau ramalan sederhana dan tuntutan seseorang terhadap orang lain untuk melakukan suatu tindakan tertentu.

Dalam konteks penelitian fenomenologi ini, perempuan yang melakukan pernikahan kembali (remarriage) setelah perceraian menginginkan pernikahan yang bahagia. Menikah lagi menjadi harapan untuk tidak merasakan kembali kegagalan pada pernikahan sebelumnya. Subjek dalam penelitian ini mengungkapkan bahwa keinginan untuk menikah lagi untuk mencapai beberapa tujuan yaitu untuk mengatasi kesulitan ekonomi, masalah kebutuhan biologis, agama, dan status social.

Selain hal-hal yang sudah diungkapkan di atas, peneliti juga dapat membuat kategori terhadap subjek penelitian berdasarkan lamanya waktu mereka menjanda. Dari kelima subjek yang sudah diwawancarai terungkap bahwa mereka berada pada rentang waktu yang beragam sampai akhirnya memutuskan untuk menikah lagi setelah perceraian. Waktu menjanda yang dimaksud ada lima yaitu mulai dari satu tahun, tiga tahun, lima tahun, 11 dan 12 tahun. Dengan demikian peneliti membuat kategori subjek yaitu short-term remarriage (menikah kembali dalam waktu yang cepat), middle-term remarriage (menikah kembali dalam waktu yang agak cepat), dan long-term remarriage (menikah kembali dalam waktu yang lama).

Sedangkan berdasarkan alasan, maka subjek penelitian dapat dikategorikan menikah lagi karena dua alasan yaitu biologis dan non biologis. Alasan biologis sangat terkait dengan kebutuhan dasar manusia adalah pemenuhan kebutuhan akan seks. Menikah kembali diambil sebagai sebuah keputusan berdasarkan alasan mendapatkan tempat penyaluran yang sah di mata agama maupun hukum. Sedangkan faktor non biologis beragam yang diungkapkan oleh subjek penelitian seperti ingin mengakhiri kesepian, mendapatkan teman berbagi suka dan duka, menghindari tekanan sosial, mengatasi persoalan ekonomi, demi status so dan sebagainya.

Alasan dan motif subjek penelitian tersebut sangat erat kaitannya dengan konsep diri yang terbentuk pada mereka. Konsep diri adalah kesadaran akan pandangan, pendapat, penilaian, dan sikap seseorang terhadap dirinya sendiri yang meliputi fisik, diri pribadi, penampilan, diri sosial dan juga etik. Konsep diri tidak begitu saja timbul pada setiap individu. Bayi yang baru lahir tidak mengerti dan tidak memiliki konsep diri namun seiring berjalannya waktu, seorang bayi akan tumbuh menjadi dewasa. Dalam pendewasaannya karena sudah mampu untuk berfikir, maka konsep diri ada dan dimiliki oleh setiap individu.

Penelitian berdasarkan konsep diri adalah untuk mengetahui bagaimana konsep diri seorang perempuan pelaku pernikahan kembali sesudah bercerai. Sehingga dapat terlihat apakah para perempuan tersebut memiliki konsep diri yang positif atau yang negatif dalam dirinya sebagai mahluk sosial. Konsep diri setiap orang jelaslah berbeda. Tidak pernah ditemukan sebuah konsep diri yang serupa dan dimiliki oleh orang yang berbeda walaupun dengan 
sepasang anak kembar sekalipun.

Dari unsur konsep diri yang ditanyakan kepada subjek penelitian untuk mengetahui interaksi simbolik perempuan pelaku pernikahan kembali, ternyata dari jawaban-jawaban yang didapat dari unsur konsep diri ini, mereka sudah memiliki konsep dirinya sendiri dan sesuai dengan harapan dan keinginan mereka sendiri. Semua subjek memiliki latar belakang yang berbeda. Baik dari pendidikan, keluarga, usia, dan pekerjaannya. Tetapi berdasarkan data yang didapat, mereka mengkonsepkan dirinya seperti itu atas dasar diri sendiri. Setidaknya lingkungan di mana dia berada sedikit mempengaruhi apa yang telah mereka konsepkan pada dirinya sendiri. Konsep diri awal dari setiap orang adalah mengenali siapa dirinya. Semakin mendekati jarak apa yang kita asumsikan tentang diri kita, itu berarti baik karena kita mengenal diri sendiri. Begitu pula sebaliknya, semakin jauh jarak antara kenyatan dengan apa yang kita perkirakan tentang diri sendiri, artinya buruk sekali pengenalan diri kita.

Begitu pula yang terjadi pada perempuan pelaku pernikahan kembali sesudah bercerai mengetahui dan mengenal dirinya dengan baik. Mereka memahami dirinya sebagai seseorang yang pernah megalami kegagalan dalam pernikahan sebelumnya.

Dari hasil harapan yang timbul dari dalam diri masing-masing subjek adalah munculnya rasa percaya diri yang tumbuh dari dalam dirinya untuk menghadapi pernikahan keduanya dengan pasangan baru. Mereka memiliki harapan memperoleh pernikahan yang lebih baik. Selain harapan dari dalam diri yang ingin diperoleh oleh seseorang, juga adanya harapan lain yang diharapkan datang dari lingkungan sosialnya. Lingkungan sosial di sini adalah lingkugan sekitar di mana mereka berada. Lingkungan perempuan yang melakukan pernikahan kembali adalah anak, suami, dan masyarakat. Dalam kehidupan sosialnya, mereka menginginkan adanya pengakuan dan penerimaan terhadap keputusannya menikah lagi sebagai sebuah perbuatan yang wajar dan dinilai positif.

Melihat semua uraian tentang motif dan alasan perempuan pelaku remarriage pasca perceraian di atas, peneliti dapat menemukan beberapa kategori yang menggambarkan konsep diri mereka. Alasan dapat dibedakan dari motif. Alasan adalah keputusan pertama menikah lagi setelah perceraian. Sedangkan motif adalah dorongan untuk tetap menjalani keputusan yang diambil. Hal ini dapat dilihat dalam kategorisasi berikut ini :

Tabel 1

Kategori Konsep Diri Perempuan yang Menikah Kembali Sesudah Bercerai berdasarkan Alasan dan Motif

\begin{tabular}{|c|c|c|c|}
\hline Alasan & Motif & Kategori & Konsep Diri \\
\hline Biologis & Masa lalu & Short -Term Remarriage & Positif \\
Ekonomi \\
$\begin{array}{c}\text { Statsus Sosial } \\
\text { Agama }\end{array}$ & & Masa depan & Negatif \\
\hline
\end{tabular}

Dari tabel di atas terlihat bahwa ditemukan empat alasan perempuan memutuskan untuk menikah lagi setelah perceraian. Alasan pertama adalah faktor biologis. Subjek mengakui bahwa kebutuhan akan seks merupakan alasan untuk menikah lagi sebagai langkah 
menghindari perbuatan dosa karena dorongan kebutuhan biologis tersebut. Sedangkan alasan ekonomi dikemukakan oleh subjek penelitian yaitu lebih dikarenakan kesulitan ekonomi yang mereka hadapi dalam menafkahi anak-anak yang merupakan hasil pernikahan pertama. Alasan lain yang juga diungkapkan oleh subjek adalah menghindari stigma negatif dari masyarakat yang menganggap status orang tua tunggal sebagai status yang mengancam bagi suami mereka. Alasan terakhir adalah agama, agar sah dan halal di mata Tuhan.

Pada kategori motif, subjek penelitian pada dasarnya menyadari bahwa kegagalan rumah tangga mereka pada pernikahan pertama disebabkan oleh berbagai faktor. Sehingga pengalaman di masa lalu itu menjadi patokan untuk melangkah dan menjalani pernikahan kembali setelah perceraian. Sehingga pada pernikahan kembali mereka memiliki harapan untuk memperoleh kehidupan yang lebih baik dalam segala sendi kehidupan.

Pada tataran konsep diri yang terbentuk pada diri subjek ada dua yaitu negatif dan positif. Pada dasarnya subjek sangat mengenali diri mereka sebagai seseorang yang pernah mengalami kegagalan pada pernikahan pertama. Mereka menyadari banyak kekurangan dalam diri mereka dan mantan suami sehingga menjadi penyebab terjadinya perceraian. Selain itu mereka juga sangat sadar bahwa kegagalan itu tidak boleh berlarut-larut tetapi mereka harus memiliki rasa percaya diri dengan pasangan baru. Jadi, konsep diri negatif terbentuk pada awal-awal masa pasca perceraian. Namun seiring berjalannya waktu konsep diri negative ini berubah menjadi positif ketika subjek menyadari bahwa kegagalan masa lalu bukan sesuatu yang harus menjadi penghalang untuk meraih masa depan dengan segala harapan yang lebih baik.

Kategori pernikahan kembali yang peneliti berikan di atas didasarkan pada lamanya waktu subjek menyandang status orang tua tunggal atau hidup menjanda. Kategori yang pertama adalah short-term remarriage yaitu keputusan untuk menikah kembali (remarriage) diambil satu tahun setelah perceraian. Sedangkan middle-term remarriage adalah keputusan menikah kembali tiga tahun setelah perceraian. Kategori yang terakhir adalah long-term remarriage adalah subjek memutuskan untuk menikah kembali lima tahun setelah perceraian.

\section{Komunikasi Adaptasi Keluarga Perempuan Pelaku Remarriage}

Seseorang yang pernah mengalami kegagalan dalam perkawinannya kemudian memutuskan untuk menikah kembali diambil sebagai langkah untuk melanjutkan kehidupan. Dengan harapan mereka dapat melalui kehidupan lebih baik jika ada pasangan dalam hidup.

Dalam sebuah perkawinan tidak terbatas hanya pada saat awal-awal menikah saja, tetapi proses penyesuaian diri dan pengenalan antar pasangan tersebut berlangsung selama masa-masa perkawinan yang dijalani. Pada masa awal pernikahan, umumnya pasangan masih berusaha mengenal satu sama lain. Banyak kebiasaan yang mungkin belum nampak saat belum menikah dan baru akan disadari setelah menikah. Biasanya pasangan akan menjaga image di depan pasangannya.

Komunikasi adaptasi dalam mencari kesamaan akan menjadi sulit, begitu juga dengan adanya dua bentuk keluarga yang akan menjadikan proses adaptasi hidup sebagai keluarga remarriage akan semakin sulit. Keadaan akan menjadi lebih kompleks jika pasangan baru orang tua turut membawa anak yang nantinya akan menjadi saudara tiri, apalagi bila dikemudian hari orang tua akan mempunyai atau menambah anak lagi dengan suami yang 
baru (punya adik atau kakak baru). Kondisi seperti ini, pada seorang anak, biasanya akan menimbulkan perasaan tersaingi karena orang tua yang dulunya hanya memperhatikan dirinya saja, kini harus membagi perhatiannya. Menerima kehadiran keluarga tiri memang sebuah hal yang sulit.

Demikian pula dengan subjek dalam penelitian ini mengalami hal yang sama dalam komunikasi adaptasi yang dilakukan dengan pasangan dan anak baik anak kandung maupun anak tiri. Ketiga subjek dalam penelitian ini dianugerahi anak dari perkawinan pertama. Demikian pula suami baru mereka, hanya satu orang yang berstatus bujang. Persoalan-persoalan yang dihadapi terkait dengan komunikasi dalam rangka melakukan adaptasi atau penyesuaian diri dengan anggota keluarga baru ditunjukkan dalam beberapa kutipan wawancara berikut.

"Saat itu Saya punya dua orang anak dari suami pertama sedangkan suami ke dua saya bujangan, Mbak. Saya juga agak bingung di awal pernikahan kami. Saya merasa harus membagi perhatian kepada anak dan suami. Kadang kalau Saya perhatikan suami, anakanak merasa kurang diperhatikan. Saya juga kasihan sama suami apalagi bujang, Mbak. Suami juga awalnya sulit mendekati anak-anak Saya. Anak Saya yang kecil, Mbak sama sekali gak mau digendong oleh bapak tirinya." (Wawancara, 9 Oktober 2015)

Wawancara dengan subjek penelitian P-2 yang memiliki dua orang anak dari suami pertama menunjukkan bahwa menikah tentu saja membutuhkan masa-masa penyesuaian diri. Ketika pasangan yang menikah lagi membawa anak dari pernikahan terdahulu maka ada dua proses penyesuaian diri yang harus dilakukan, dengan pasangan dan dengan anak. Sementara itu kehadiran anak cenderung membuat masa bulan madu menjadi hilang. Biasanya pasangan justru akan memfokuskan perhatiannya pada aktivitas mengasuh anak, padahal masa bulan madu dibutuhkan untuk mempererat ikatan dalam pernikahan.

Selain itu seseorang dengan status "orang tua tiri” yang melekat pada diri mereka seringkali mendapatkan hambatan dalam membangun komunikasi dengan anak tiri mereka pada masa awal pernikahan. Hubungan yang baik antara orang tua tiri dan anak tidak hanya ditentukan oleh keinginan dan usaha orang tua tiri, tapi juga ditentukan oleh kesiapan anak dan perkembangan anak.

Hal lain yang terungkap dari wawancara tersebut ketika orang tua memutuskan untuk menikah dengan orang lain, anak biasanya mempersepsi pernikahan kedua sebagai hilangnya kasih sayang dari orang tua kandung mereka. Anak merasa harus berkompetisi dengan orang tua tiri karena orang tua kandung akan lebih memperhatikan pasangan barunya. Ini adalah tantangan bagi orang tua kandung untuk bisa menempatkan diri secara adil.

Sedangkan pengalaman subjek penelitian lainnya, P-1 berbeda lagi. Anak-anaknya dari pernikahan pertama mendapatkan kesulitan dalam menyesuaikan diri dengan keluarga besar suami barunya. Tugas ini paling berat dirasakan karena hubungan di keluarga besar akan semakin kompleks dengan melibatkan saudara kandung dan saudara tiri, belum lagi sampai relasi dengan kakek nenek. Hubungan keluarga besar dari orang tua tiri cenderung akan lebih berjarak, berpotensi konflik, dan diwarnai interaksi negatif dibandingkan dengan keluarga besar dari orang tua kandung. Namanya juga keluarga yang baru dikenal, tentu butuh waktu untuk saling memahami karakteristik kepribadian masing-masing.

Berbeda dengan pengalaman P-4 dan P-5 dalam proses adaptasi dengan suami kedua dan 
anak-anak mereka, baik anak kandung maupun anak tiri. Mereka mengaku tak ada kendala yang berarti selama mengarungi biduk rumah tangga. Seperti yang diungkapkan oleh P-5 :

"Hubungan Saya dengan suami dan anak-anak tiri sangat baik. Mungkin karena Saya memang ingin punya anak ya. Kami seperti sahabat, saling curhat. Terutama saat suami Saya lembur atau tugas ke luar kota. Karena tugasnya sebagai seorang wartawan membuatnya sering sekali menghabiskan waktu di luar rumah. Tapi Saya tetap bahagia, kan ada anak-anak yang menemani di rumah. Bahkan mereka lebih terbuka dengan Saya dibanding ayahnya sendiri. Kami sering nonton di bioskop barenga atau berwisata kuliner di luar rumah. Hal itulah yang Saya syukuri...berarti Saya telah memperoleh kepercayaan mereka" (Wawancara, 17 Oktober 2015)

Sementara itu, P-4 merasa tak punya masalah dengan proses penyesuaian diri antara Dirinya, suami dan anak-anak bawaan mereka masing-masing. Berikut pengakuannya :

"Putra Saya dan putri suami sangat akrab, mungkin karena mereka seumuran. Samasama berstatus mahasiswa. Putra Saya terlihat sangat ngemong dan mengayomi adiknya. Suami juga bersikap tak membeda-bedakan keduanya. Yah....alhamdulillah, Mbak. Suami juga sangat terbuka, hal sekecil apapun selalu didiskusikan dengan Saya, kadang juga melibatkan anak-anak. Situasi seperti ini membuat saya merasa dihargai... merasa di'wong'ke" (Wawancara, 19 Oktober 2015).

Subjek penelitian P-3 yang menikah dengan suami kedua yang terpaut umur 10 tahun dengannya menghadapi masalah yang berbeda. Masalah yang timbul dalam proses penyesuaian diri dengan pasangan baru tersebut lebih disebabkan karena kondisi ekonomi. Perempuan 30 tahun ini tidak memiliki pekerjaan tetap sementara suami barunya hanya karyawan di sebuah dealer motor. Kesulitan-kesulitan keuangan kerap mereka temui dan menjadi pemicu terjadinya konflik seperti penuturannya di bawah ini:

"Dulu...kalau di akhir bulan suami sering mendiamkan Saya. Dia gak ngomong apaapa, Mbak. Saya juga bingung jadinya. Ternyata setelah Saya tanya, dia begitu karena memikirkan masih ada kebutuhan yang belum terpenuhi padahal uang kami bulan itu tinggal sedikit. Parahnya lagi, Mbak, Dia sering membanding-bandingkan kondisi keuangannya pada pernikahan pertamanya yang lebih mapan karena mantan istrinya juga kerja". (Wawancara, 11 Oktober 2015)

Berdasarkan hasil wawancara dengan subjek penelitian tersebut menunjukkan bahwa setiap individu yang menikah dan membentuk keluarga akan mengalami tahap penyesuaian diri oleh adanya perbedaan pandangan, pengalaman hidup, aturan, serta sikap dan perilaku. Perbedaan-perbedaan tersebut dapat menjadi penyebab terjadinya konflik. Untuk membentuk keluarga yang harmonis, maka dibutuhkan komunikasi yang efektif, pembagian peran (tugas) bagi tiap anggota keluarga, serta cara yang baik pula dalam mengelola dan menyelesaikan konflik.

Hal tersebut diakui oleh subjek dalam penelitian ini yang menyebabkan kegagalan pernikahan pertama. Keintiman keluarga dan penyelesaian segala masalah yang muncul dapat ditempuh dengan membangun komunikasi yang baik di antara anggota keluarga yang ada.

"Saya menyadari bahwa pernikahan saya sebelumnya penuh konflik karena saya dan 
mantan suami tidak mampu mengkomunikasikan keinginan masing-masing. Mungkin waktu pacaran kami kurang membahas hal-hal penting. Alhasil tiga tahun pertama penuh cekcok sampai saya memutuskan pergi dari rumah dan bercerai. Saya lebih siap dengan pernikahan yang ke dua dan Saya dengan suami sudah buka-bukaan sampai hal yang sensitif". (Wawancara, 9 Oktober 2015)

Dari pemaparan P-2 (30 tahun) tersebut menunjukkan bahwa setiap pasangan yang akan menikah kembali memiliki harapan besar untuk bisa membangun kehidupan rumah tangga yang lebih baik. Masing-masing telah berproses untuk melihat kelemahan dari relasi yang mereka bangun dengan pasangan sebelumnya. Berbekal pengetahuan ini, mereka pun cukup yakin bisa menjalani rumah tangga keduanya secara lebih baik.

Sementara P-1 yang sempat mengarungi pernikahan pertamanya selama 10 tahun harus mengakui bahwa profesi mantan suami sebagai pejabat akuntan yang dihadapkan dengan berbagai kesibukan urusan dinas menjadi pemicu prahara dalam rumah tangga mereka saat itu. Jarangnya mereka berkomunikasi menyebabkan persoalan-persoalan yang muncul tidak dapat mereka selesaikan dengan baik hingga akhirnya perceraian menjadi jalan terkahir bagi mereka. Perempuan yang mengabdikan dirinya sebagai Guru TK ini sering tidak percaya akan kesibukan suami dan dianggapnya sebagai bentuk ketidakpeduliannya pada keluarga seperti yang ia utarakan sebagai berikut:

"Mantan suami Saya dulu seorang akuntan. Namanya juga kerja di bidang keuangan pasti sering lembur dan harus pergi ke kantor cabang untuk melakukan audit. Saya dulu sering marah dan menuduh suami egois. Saya pikir dia terlalu sibuk dengan pekerjaannya dan melupakan Saya dan anak-anak. Tapi saat itu Saya jarang sekali bilang sama suami, Saya pendam terus sampai akhirnya kami ribut. Begitu seterusnya". (Wawancara, 8 Oktober 2015)

Jelas bahwa kita sebagai manusia terkadang tak luput dari kesalahan. Seseorang boleh kesal, marah, dan kecewa dengan keadaan. Siapapun itu, perasaan kecewa maupun marah sangat normal dialami. Berbagai cara ditempuh untuk menunjukkan perasaan itu. Bagi subjek penelitian yang satu ini, P-3, memilih diam ketika terjadi konflik.

"Dulu Saya sering diam kalau lagi kesal. Saya jarang ngomong ke suami tentang apa yang Saya rasakan. Tapi diamnya Saya ternyata tidak bikin masalah jadi teratasi,Mbak. Tujuan Saya sih, biar gak ribut sama suami". (Wawancara, 11 Oktober 2015)

Hasil wawancara dengan subjek penelitian tersebut mengindikasikan bahwa komunikasi adalah suatu kebutuhan yang sangat fundamental bagi seseorang dalam hidup bermasyarakat. Komunikasi juga merupakan prasyarat kehidupan manusia. Kehidupan manusia akan tampak hampa bila tidak ada komunikasi. Jadi pada dasarnya manusia telah melakukan tindakan komunikasi sejak ia lahir ke dunia.

Setelah beranjak dewasa ia ingin mengetahui lingkungan sekitarnya, bahkan ingin mengetahui apa yang terjadi dalam dirinya. Rasa ingin tahu ini memaksa manusia perlu berkomunikasi. Jika orang tidak pernah berkomunikasi dengan orang lain niscaya ia akan merasa terisolasi dari masyarakatnya.

Sebagai makhluk sosial manusia senantiasa ingin berhubungan dengan manusia lainnya. 
Manusia ingin berkomunikasi dengan manusia lainnya itu karena adanya dua kebutuhan, yakni kebutuhan untuk mempertahankan kelangsungan hidupnya dan kebutuhan untuk menyesuaikan diri dengan lingkungannya.

Di manapun manusia melakukan proses komunikasi dengan lawan bicaranya baik di lingkungan masyarakat, tempat bekerja, sekolah, keluarga, maupun organisasi. Namun di antara lingkungan yang ada, keluargalah yang sangat mempengaruhi kehidupan seseorang dikarenakan intensitas dan frekuensinya yang cenderung tetap dan rutin. Keluarga adalah lingkungan di mana beberapa orang yang masih memiliki hubungan darah.

Komunikasi dalam keluarga adalah bentuk komunikasi yang paling ideal. Karena hirarki antara orang tua dan anak ada tapi tidak menyebabkan formalitas komunikasi di antara mereka. Perbedaan latar belakang budaya, pendidikan, usia, kebiasaan dan kepribadian antar anggota keluarga khususnya suami istri harusnya tidak menjadi penghalang untuk berkomunikasi. Sejak sepasang insan menikah, komunikasi dua keluarga besar dimulai secara intensif. Modal mereka tidak hanya kasih tapi juga platform yang sama, berdasarkan janji nikah.

Namun pada kenyataannya, tidak semua keluarga dapat memenuhi gambaran ideal sebuah keluarga yang baik. Perubahan sosial, ekonomi, dan budaya dewasa ini telah banyak memberikan hasil yang menggembirakan dan berhasil meningkatkan kesejahteraan masyarakat. Namun demikian pada waktu bersamaan, perubahan-perubahan tersebut membawa dampak yang tidak menguntungkan bagi keluarga. Misalnya adanya gejala perubahan cara hidup dan pola hubungan dalam keluarga karena berpisahnya suami, ibu dengan anak dalam waktu yang lama setiap harinya. Kondisi yang demikian ini menyebabkan komunikasi dan interaksi antara sesama anggota keluarga menjadi kurang intens. Hubungan kekeluargaan yang semula kuat dan erat, cenderung longgar dan rapuh.

Rawannya terjadi berbagai konflik antar-komponen keluarga tersebut dapat mempengaruhi keharmonisan dan kenyamanan di dalamnya. Tentunya konflik yang terjadi tidak boleh dibiarkan berlarut-larut. Sehingga dapat dikatakan bahwa dalam pola hubungan yang terjadi dalam sebuah keluarga apalagi pada keluarga yang pelaku pernikahan kembali sesudah bercerai diperlukan komunikasi dalam proses adaptasi. Perlu disadari bahwa komunikasi memiliki peran yang sangat penting dalam kehidupan manusia. Begitu banyak dampak atau efek yang diakibatkan oleh kegagalan komunikasi di dalam sebuah keluarga, unit terkecil dari masyarakat yang seharusnya memiliki intensitas dan kualitas komunikasi yang baik.

\section{PENUTUP A.}

\section{Kesimpulan}

Berdasarkan data di lapangan dengan didukung oleh teori-teori (Teori Tindakan Sosial dan Interaksi Simbolik), dimana penelitian ini bertujuan mengetahui perempuan yang melakukan pernikahan kembali sesudah bercerai mengkonstruksi realitas sosial mereka menurut pandangan mereka sendiri dan mengetahui proses komunikasi dalam adaptasinya. Berikut kesimpulan yang diperoleh dalam penelitian ini :

1. Konstruksi realitas menurut perempuan yang melakukan pernikahan kembali sesudah bercerai meliputi proses yang mengungkapkan alasan, motif, dan konsep diri yang mereka 
miliki sehubungan dengan pilihan hidupnya tersebut. Dari hasil penelitian ditemukan bahwa subjek memutuskan untuk menikah kembali setelah perceraian karena alasan biologis, ekonomi, dan sosial/agama. Sedangkan motifnya berorientasi masa lalu dan masa depan sehingga konsep diri yang terbentuk pada masa awal pasca perceraian adalah konsep diri negatif dan konsep diri positif mulai terbentuk ketika mereka memutuskan untuk menikah lagi pasca perceraiannya.

2. Proses komunikasi perempuan yang melakukan pernikahan kembali sesudah bercerai dalam adaptasi dengan keluarga barunya membutuhkan waktu yang cukup lama untuk saling memahami satu sama lain. Proses penyesuaian diri tersebut menemui banyak hambatan komunikasi. Sikap diam dan terkesan menghindar ditunjukkan oleh subjek penelitian ketika ada hal-hal yang mengganggu perasaan mereka dalam hubungan dengan keluarga baru. Namun akhirnya mereka menyadari bahwa adaptasi yang dilakukan harus didukung oleh komunikasi yang terbuka untuk mengungkapkan segala persoalan yang dihadapi agar menemukan cara penyelesaiannya.

\section{B. Saran}

1. Penelitian ini menggunakan teknik pengumpulan data dengan cara wawancara mendalam (Indepth Interview). Di penelitian mendatang hendaknya menggunakan Focuss Group Discussion (FGD). Dengan FGD, hasil penelitian diharapkan informasi dari para subyek penelitian dapat digali dengan lebih mendalam.

2. Pemilihan subyek penelitian yang akan datang, hendaknya tidak hanya di Pulau Jawa saja, tetapi juga dilakukan pada para subyek di luar Pulau Jawa. Sehingga diharapkan hasil penelitian lebih variatif, karena terdapat perbedaan budaya, bahasa, kebiasaan, dan adat-istiadat setempat. 


\section{DAFTAR PUSTAKA}

Islami, M,Irfan. [2001]. Filsafat Ilmu dan Metodologi Penelitian, Bahan Kuliah Program Doktor Ilmu Administrasi Universitas Brawijaya Malang.

Kuswarno, Engkus. [2009]. Metodologi Penelitian Komunikasi, Fenomenologi, Konsepsi, Pedoman dan Contoh Penelitian. Bandung : Widya Padjadjaran.

Littlejohn, Stephen W. dan Karen A. Foss. [2011]. Teori Komunikasi (Theories of Human Communication). Edisi 9. Jakarta: Salemba Humanika.

Mulyana, Deddy, Solatun. [2007]. Metode Penelitian Komunikasi; Contoh-contoh Penelitian Kualitatif dengan Pendekatan Praktis. Bandung : PT. Remaja Rosdakarya.

[2008]. Metodologi Penelitian Kualitatif, Paradigma Baru Ilmu Komunikasi dan Ilmu Sosial Lainnya. Bandung : PT Remaja Rosdakarya.

Schutz, Alfred. [1967]. The Phenomenology of The Social World, Evanston : Illinois Northwestern University Press.

West,Richard, Turner,Lynn H. [2010]. Pengantar Teori Komunikasi.Analisis dan Aplikasi (Introducing Communication Theory:Analysis and Application).edisi 3, Jakarta:Salemba Humanika. 